\title{
The Role of Tyrosine Phosphorylation in Regulation of Signal Transduction Pathways in Unicellular Eukaryotes
}

Irina V. Schemarova

Sechenov Institute of Evolutionary Physiology and Biochemistry, Russian Academy of Sciences, St. Petersburg 194223, Russia

\begin{abstract}
The review summarizes for the first time the current concepts of the role of tyrosine phosphorylation in regulation of signal transduction pathways in unicellular eukaryotes. Evolutionary concepts are developed about the origin of protein tyrosine kinases (PTK)-signaling.
\end{abstract}

\section{Introduction}

At the end of the last century, in mammalian cells a multicascade pathway was discovered to be responsible for transmission of proliferative signals into genome. The key role in the signal transmission through this pathway is played by processes of phosphorylation of protein tyrosine residues (Hunter, 1995; Marshall, 1995; Feig et al., 1996; Mustelin et al., 2002).

Ushiro and Cohen (1980) were the first to establish the important role of phosphorylation of tyrosine as a regulator of intracellular processes and to reveal changes of tyrosine kinase activity of proteins in mammalian cells in response to action of growth factors. Subsequently, the change of the protein tyrosine kinase activity was shown to underlie the Ras-MAPK signaling pathway regulated by Mitogen-Activated Protein (MAP) kinases (Hunter and Cooper, 1985).

Phosphorylation of tyrosine residues in proteins is catalyzed by retrovirus protein tyrosine kinases (PTKs), their cellular homologues (Bishop, 1983) or by tyrosine kinases associated with growth factor receptors (Yarden and Ullrich, 1988; Broome and Hunter, 1996). These proteins were studied in detail and classified in vertebrate animals (Hanks and Hunter, 1995).

The classical scheme of transmission of the proliferative signals through the pathway mediated by growth factors (Ras-MAPK pathway) includes: (1) association of growth factor with receptor, (2) dimerization of receptor and autophosphorylation of receptor tyrosine kinase (RTK), (3) module coupling of RTK with adaptor SH2-domain proteins; activation of Ras, (4) phosphorylation and activation of MAP kinases, (5) transmission of signal into genome.

At the end of the last century, another pathway of transmission of proliferative signals into genome, with participation of growth factors and tyrosine kinases, was discovered (Shuai et al., 1994). This is the monocascade STAT pathway activated by receptors of growth factors and cytokines. The essence of this transmission consists in direct activation by tyrosine kinases of the STAT (signal

For correspondence: Irina@lis.mail.iephb.ru transducer and activator of transcription) proteins located in the cytoplasm. This transmission is also provided by the SH2-domain contacts responsible for coupling of phosphotyrosine-containing proteins (Darnell, 1997).

The structural-functional organization of Ras-MAPK and STAT signaling pathways in vertebrate cells has been intensively studied for more than 20 years. By the present time an extensive experimental material has been accumulated, which allows judging about the events in cells of the higher eukaryotes at each stage of transmission of proliferative signal. Much less is known about mechanisms of transmission of growth signals in cells of primitive eukaryotes. There are practically no data in the literature about the existence of their STAT and RasMAPK pathways of the signal transmission; meanwhile, it is obvious that RTKs exist not only in mammals, but in multicellular invertebrates, including the most primitive - sponges and coelenterates (Schartl, Barnekow, 1982; Schartl et al., 1989; Kruse et al., 1997).

Our analysis of experimental and literature data has shown that tyrosine phosphorylation also takes place in cells of unicellular eukaryotes. The presence in eukaryotic microorganisms of tyrosine kinases and proteins phosphorylated at tyrosine in processes of growth, cellular differentiation, and adaptive response indicates a more ancient origin of mechanisms of PTKsignaling than this was believed earlier.

This review focuses on the role of mammalian growth factors, tyrosine kinases, and phosphotyrosine-containing proteins in signaling in unicellular eukaryotes.

\section{Effects of mammalian growth factors on unicellular organisms}

Due to the accepted concept that PTK-signaling takes place only in cells of the higher eukaryotes, many aspects of the problem of evolutionary origin of this signaling are kept in the shade. Thus, for instance, nothing, in fact, is known about evolution of mechanisms of activation of the signal pathways dependent on tyrosine phosphorylation.

In this connection, it seems important to consider pathways of signal transmission by tyrosine phosphorylation in unicellular eukaryotes, whose cells have no typical growth receptors and RTKs.

It would have been logical to suggest that unicellular eukaryotes deprived of typical receptors of mammalian growth factors could not and should not respond to signals initiated by mammalian growth factors. However, in reality, this is not so. Studies performed for the last few years have shown that the mammalian growth factors (TGF $\alpha$, EGF, FGF, HGF, etc.) can initiate proliferative effect not only in mammalian cells, but also in unicellular animals. The stimulating effect of mammalian growth factors on proliferative growth of eukaryotic microorganisms was revealed for the first time in the parasitic protozoa Giardia lamblia (Lujan et al, 1994). The mitogenic effect on 
growth of $G$. lamblia was produced by insulin-like factors IGF-I and IGF-II (Lujan et al, 1994). They were shown to accelerate growth and L-cysteine incorporation in $G$. lamblia trophozoites cultivated axenically in a serumfree medium. The insulin-like factors act through the parasite membrane glycoprotein that has immunological characteristics similar to those of the mammalian IGF-I. In reaction of immunoprecipitation of lysate of $G$. lamblia trophozoites incubated with human recombinant IGF-II, with monoclonal antibody $\alpha \mathrm{IR} 3$, proteins of a molecular mass of $70 \mathrm{kDa}$ were found; one of them, as shown by further studies using polyclonal antibody to the IGFI receptor, corresponded to the IGF-I receptor $\alpha$-chain. Protein of a molecular mass of $95 \mathrm{kDa}$ that corresponded to the receptor IGF-I $\beta$-chain was discovered using polyclonal antibody to phosphotyrosine. Based on the obtained data, the authors suggested the existence in the membrane glycoproteins of G. lamblia trophozoites of internal tyrosine kinase activity and the capability for autophosphorylation.

The promoter effect of IGF-I on cell growth was also revealed in cells of the parasitic protozoa Leishmania mexicana (Gomes et al., 1998; 2001). The authors explain the stimulating IGF-I effect on leishmanian cells by a similarity of structure in receptors of leishmanian and mammalian cells. The receptor for IGF-I on L. mexicana promastigotes is a monomeric glycoprotein of a molecular mass of $65 \mathrm{kDa}$ and is antigenically related to the $\alpha$-chain of the human type 1 IGF-I receptor. Upon IGF-I stimulation the receptor undergoes autophosphorylation at tyrosine residues with activation of its signaling pathway. Activation of the IGF-I receptor also leads to phosphorylation of a $185-\mathrm{kDa}$ molecule that is homologous to the substrate of the insulin receptor present in human cells, the insulin receptor substrate 1 (IRS-1) (Gomes et al., 2001).

By the example of free-living ciliates Tetrahymena pyriformis and Tetrahymena thermophila, the vertebrate insulin also was shown to be capable of changing the cell metabolism level and the growth rate of the protozoa (Christopher and Sundermann, 1996; Shemarova et al., 2002). In experiments on a combined use of epidermal growth factor (EGF) and insulin, it was found that the mitogenic effect on tetrahymena was evoked by progression of cells in $G_{1}$-phase under the action of growth factors and hence by an earlier entry into S-phase of the first cell cycle. Insulin repressed division of the cells entering the generative cycle, as the cells were delayed at the late S-phase and $G_{2}$-phase of the cycle; under these circumstances one part of the population was lost and another part overcame the cell block successfully and started dividing by $4 \mathrm{hr}$ of cultivation (Shemarova et al., 2002).

The stimulating effect on growth of the parasitic protozoa Trypanosoma musculi was also produced by mammalian fibroblast growth factor (FGF). It was established that in the fibroblast-free serum medium, the T. musculi cells cultivated in vitro turned out to be unable to normally grow; they lost the capability for division and infectivity. These properties were retained only in trypanosomes growing in contact with FGF-producing fibroblasts. In immunocytochemical studies the parasites were found to contain the FGF-activated cytoskeleton and membrane-associated proteins that, in the authors' opinion (Gugssa et al., 2000), became involved in control of growth and reproduction of T. musculi.

Platelet growth factor (PDGF), whose receptors in mammals also have their own tyrosine kinase activity, stimulated macromolecular synthesis in the ciliate Tetrahymena pyriformis (Andersen et al., 1984). Measurements of changes in the labeled uridine specific activity in the UTP pool after PDGF treatment showed an initial increase lasting for about $40 \mathrm{~min}$. Thereafter the RNA synthesis rate gradually decreased and became the same as in intact cells after $2 \mathrm{hr}$ of incubation. PDGF also stimulated the labeled uridine incorporation in $T$. pyriformis. The increase begins shortly after addition of this growth factor and levels off 2-3 $\mathrm{h}$ later. The data obtained by these authors (Andersen et al., 1984) rule out a possibility of induction of changes in the nucleotide pool of precursors both of RNA and of DNA by PDGF in $T$. pyriformis. The authors suggested T. pyriformis to contain receptors on its surface for the growth factor.

Colony-stimulating growth factor (CSF) from granulocytes stimulated proliferative response and inhibited the heat-shock-induced apoptosis in Leishmania mexicana amazonensis (Charlab et al., 1990; Barcinski et al., 1992; Welburn et al., 1996). Some mammalian cytokines (IL-3, IL-6, TNF, and IFN- $\gamma$ ) are reported to induce in protozoan parasites a cellular reaction aimed at maintaining their viability (Olsson et al, 1992; Barcinski, Moreira, 1994; Csaba et al., 1995, Salotra et al., 1995; Bakhiet et al., 1996).

Several works have demonstrated stimulation of proliferation of protozoa by EGF (Hide et al., 1989; Sternberg, McGuigan, 1994; Selivanova et al., 2002; Shemarova et al., 2004). It was established that EGF produced a marked proliferative response in vivo in trypomastigotes of the Trypanosoma brucei strain Tc221 (Sternberg and McGuigan, 1994). A significant increase of the growth rate of the trypomastigotes was observed using both human recombinant EGF and the mouse salivary gland EGF at concentrations of 20 and $200 \mathrm{nM}$, respectively. The doubling time of the cell population for the first $24 \mathrm{hr}$ of exponential growth for the trypanosomes incubated with EGF amounted to $5.9 \mathrm{hr}$, whereas for intact trypanosomes, to $6.7 \mathrm{hr}$. Similar results were obtained in experiments evaluating the EGF proliferative effect on T. brucei strain AnTaT1,1: the doubling time of experimental cultures was $5.6 \mathrm{hr}$ versus $7.1 \mathrm{hr}$ in intact cells. When trypanosomes were cultivated with addition of serum-free medium longer than for $24 \mathrm{hr}$, proliferation both of experimental and of control cultures gradually ceased. It was suggested that the proliferative EGF effect on trypanosomes was due to activation of the trypanosome EGFR-like membrane protein whose structure has a partial similarity with the extracellular domain of the human EGF receptor (EGFR) (Hide et al., 1989). Recently, new evidences have appeared in favor of structural similarity of individual fragments of the human EGFR extracellular domain and of EGFR-like protein of Trypanosoma cruzi amastigote forms (Ghansah et al., 2002). Scatchard analysis showed a single class of receptors with a $\mathrm{Kd}$ of $0.8 \mathrm{nM}$ and numbering $3.1 \times 10(3)$ per amastigote. Results from internalization experiments 
provided evidence for receptor-mediated endocytosis of EGF. Northern analysis showed a 3.0-kb transcript for the EGFR extracellular domain motif homologue in amastigotes, but not in trypomastigotes. Binding of EGF to amastigotes induced signal transduction events. EGF induced in vitro kinase activity as determined by $\gamma-\left[{ }^{32} \mathrm{P}\right]-$ ATP incorporation into amastigote proteins. EGF also increased protein kinase $\mathrm{C}$ activity and MAP kinase activity in the time- and concentration-dependent manner. A specific inhibitor (AG14782) of the EGFR and a MAP kinase inhibitor (PD98059) decreased the EGF-dependent $T$. cruzi MAP kinase activity. These results describe a novel mechanism used by amastigotes to regulate their proliferation mediated by an EGF-dependent signal transduction pathway.

The obtained data indicate a stimulating role of EGF in growth of trypomastigotes via activation of EGFRlike proteins and pose a question about its principal significance in signaling in these protozoa.

Thus, by the present time, proofs have been accumulated for the mitogenic action of mammalian growth factors on unicellular eukaryotes. Several protozoa have been found to have receptor-like proteins that have a structural similarity with growth receptors from mammalian cells. Proteins with tyrosine kinase activity have been revealed. The MAP kinase activated by human EGF has been detected. This proves the existence in several protozoa of signal pathways similar functionally with mammalian Ras-MAPK pathways. Their biological effect seems to be mediated by specific membrane sensors that have structural homology with mammalian growth factor receptors. Further study of molecular organization of the receptor-like molecules and their activated signal proteins as well as determination of induced genes is certainly to lead to a better understanding of mechanisms of action of mammalian growth factors on unicellular eukaryotes.

\section{Phosphotyrosine-containing proteins and tyrosine kinases in unicellular eukaryotes}

Cytoplasmic targets of action of protein tyrosine kinases in the lower eukaryote cells are numerous low-molecular proteins, the function of most of them yet remaining nonelucidated. Thus, according to data of phosphoamino acid analysis, insulin induces in the lower fungus Neurospora crassa phosphorylation of 14 proteins at serine, threonine, and tyrosine residues (Kole and Lenard, 1991). In solubilized membrane $N$. crassa fraction, insulin stimulated phosphorylation of 6 proteins at serine and tyrosine residue. A phosphotyrosine-containing protein of $38 \mathrm{kDa}, \mathrm{pH} 7.0-7.2$, reacted at both immunoblotting and immunoprecipitation with antiserum to $\mathrm{P} 2$, a peptide from the human insulin receptor that contains autophosphorylated tyrosine residue. Tyrosine kinase activity was revealed in phosphoprotein of a molecular mass of $50 \mathrm{kDa}$ when histone $\mathrm{H} 2$ was used as substrate (Fawell and Lenard, 1988). In the slime mold Dictyostelium discoideum, phosphotyrosine-containing proteins of molecular masses of 205-220 kDa were revealed (Schweiger et al., 1990). The presence of phosphotyrosine in $D$. discoideum proteins was established both from $\left[{ }^{32} \mathrm{P}\right]-$ phosphate incorporation in vivo and in cell lysates with the aid of monoclonal antibody to phosphotyrosine in vitro. In the process of the initial growth phase of $D$. discoideum, phosphotyrosine-containing proteins of molecular masses of 205-220, 107, and 60 kDa were found; phosphorylation at tyrosine of protein with a molecular mass of $60 \mathrm{kDa}$ was very low in this development phase of the myxomycete life cycle. Throughout the entire period of the fungal spore development an intensive phosphorylation at tyrosine of proteins of molecular masses of 205-220 and 107 kDa was observed; it decreased by $22 \mathrm{hr}$ when the cell differentiation of $D$. discoideum spores was completed. At the same time, phosphorylation of tyrosine-containing proteins of a molecular mass of $60 \mathrm{kDa}$ rose significantly in the differentiation phase and remained elevated during the whole period of the fruiting body formation; this indicates an important role of various tyrosinecontaining $D$. discoideum proteins in the process of growth and differentiation. Recent investigations of effect of activated RasG on the phosphorylation state of $D$. discoideum proteins have shown that out of 70 vegetative phosphoprotein components resolved by two-dimensional (2-D) immunoblot analysis, three components were phosphotyrosine proteins (Secko et al., 2004). These data directly indicate participation of phosphotyrosine proteins in dictyostelium PTK-signaling.

By identification of phosphoamino acids in immunoprecipitation reaction the phosphotyrosinecontaining proteins were revealed to contain, apart from phosphotyrosine, also phosphoserine and phosphotreonine. Studies with renatured proteins showed that, like RTK, at least one tyrosine kinase of $D$. discoideum was capable for autophosphorylation (Schweiger et al., 1990). The authors suggested that the phosphotyrosinecontaining protein of a molecular mass of $60 \mathrm{kDa}$ that is present in many multicellular animals could be related to a product of the gene $c$-src, while proteins forming bands in the area of 200-300 kDa could be receptor-like tyrosine kinases involved, like in the higher eukaryotes, in control of proliferation and differentiation (Table 1). The presence of receptor-like tyrosine kinases in $D$. discoideum was confirmed in the work of Adler et al. (1996). Based on results of molecular cloning and phylogenetic analysis, two kinases, DPYK3 and DPYK4, were concluded to belong to this RTK group. $\mathrm{COOH}$-terminal fragments of each kinase are capable for autophosphorylation at tyrosine residues. These fragments were recognized in immunoblots by $\mathrm{mAb}$ 5E2 - monoclonal antibody to phosphotyrosine. However, analysis of the primary structures showed these enzymes, unlike classic RTK, to contain neither transmembrane segments nor $\mathrm{SH} 2$ domains. Like in RTK, in DPYK3 the domain I was functioning (from Lys-1050 to Met-1304), as well as possibly the more truncated domain II (from Thr812 to Leu-1008). In DPYK4, only the domain I belongs to the tyrosine kinase branch of protein kinases. The tyrosine kinase ZAK1 (Table 1) is a downstream target of serpentine receptor cAR1 (Kim et al., 1999). It is required for GSK3 activation during multicellular development of D. dictyostelium.

Tyrosine kinases and phosphotyrosine-containing proteins were also revealed in various representatives of protozoa. Thus, tyrosine kinase-like activity was found in trophozoites and schizonts of Plasmodium falciparum; an inhibitory effect of the antimalarian drug piceatannol on 


\begin{tabular}{|c|c|c|c|c|c|c|}
\hline \multirow[b]{2}{*}{ Species of the organism } & \multirow[b]{2}{*}{$\begin{array}{l}\text { Name of } \\
\text { kinase }\end{array}$} & \multicolumn{4}{|c|}{ Properties of tyrosine kinases } & \multirow[b]{2}{*}{ Reference } \\
\hline & & Size, kDa & Peculiar properties & $\begin{array}{l}\text { Names of sub- } \\
\text { strates }\end{array}$ & Function & \\
\hline D. discoideum & PTKs & $\begin{array}{l}60, \text { and about } \\
200 \text { to } 300\end{array}$ & $\begin{array}{l}\text { The presence of extracellular } \\
\text { domain with the RTK activity } \\
\text { is proposed }\end{array}$ & Not identified & $\begin{array}{l}\text { Control of multicel- } \\
\text { lular development }\end{array}$ & $\begin{array}{l}\text { Schweiger et } \\
\text { al., } 1990\end{array}$ \\
\hline D. discoideum & $\begin{array}{l}\text { DPYK3 } \\
\text { DPYK4 }\end{array}$ & $\begin{array}{l}150 \\
75\end{array}$ & $\begin{array}{l}\text { C-terminal fragments of each } \\
\text { protein are shown to be au- } \\
\text { tocatalytically phosphrylated } \\
\text { at tyrosine residues. The } \\
\text { common feature of these ki- } \\
\text { nases is the presence of two } \\
\text { different sequence stretches } \\
\text { in tandem that are related to } \\
\text { kinase catalytic domains }\end{array}$ & Not identified & Not established & $\begin{array}{l}\text { Adler et al., } \\
1996\end{array}$ \\
\hline D. discoideum & ZAK1 & No data & Downstream of GPCR & GSK3 & $\begin{array}{l}\text { ZAK1 phosphory- } \\
\text { lates and activates } \\
\text { GSK3 for cell fate } \\
\text { specification }\end{array}$ & Kim et al., 1999 \\
\hline D. discoideum & $\begin{array}{l}\text { JAK-like } \\
\text { kinase }\end{array}$ & No data & Activates STAT & DdSTAT & $\begin{array}{l}\text { JAK/STAT regu- } \\
\text { lates development } \\
\text { of stalk cells during } \\
\text { the multicellular } \\
\text { part of the life } \\
\text { cycle. Participates } \\
\text { in control of cell } \\
\text { movement }\end{array}$ & $\begin{array}{l}\text { Dearolf, 1999; } \\
\text { Hou et al., } \\
2002\end{array}$ \\
\hline D. discoideum & PTK & No data & No data & PLA2 & $\begin{array}{l}\text { Through PLA2 acti- } \\
\text { vation can regulate } \\
\mathrm{Ca}^{2+} \text { influx }\end{array}$ & $\begin{array}{l}\text { Schaloske } \\
\text { and Malchow, } \\
1997\end{array}$ \\
\hline L. donovani & PTK & About 110 & No data & No data & $\begin{array}{l}\text { Initiates host cell } \\
\text { invasion }\end{array}$ & $\begin{array}{l}\text { Salotra et al., } \\
2000\end{array}$ \\
\hline L. mexicana & PTK & 65 & $\begin{array}{l}\text { Upon IGF-I stimulation the } \\
\text { receptor undergoes auto- } \\
\text { phosphorylation at tyrosine } \\
\text { residues }\end{array}$ & No data & $\begin{array}{l}\text { Initiates host cell } \\
\text { invasion }\end{array}$ & $\begin{array}{l}\text { Gomes et al., } \\
1998,2001\end{array}$ \\
\hline P. falciparum & PTK & No data & $\begin{array}{l}\text { The PTK activity associ- } \\
\text { ated with cell membrane. } \\
\text { Chloroquine and piceatannol } \\
\text { inhibited the PTK activity }\end{array}$ & No data & $\begin{array}{l}\text { PTK is implicated } \\
\text { in growth and para- } \\
\text { site maturation }\end{array}$ & $\begin{array}{l}\text { Sharma and } \\
\text { Mishra, 1999; } \\
\text { Mishra et al., } \\
\text { 1999; Sharma, } \\
\text { 2000; Sharma } \\
\text { et al., } 2000\end{array}$ \\
\hline T. thermophila & PTK & No data & $\begin{array}{l}\text { PTK inhibitors blocked che- } \\
\text { moattraction }\end{array}$ & No data & $\begin{array}{l}\text { PTK is implicated } \\
\text { in chemoattraction }\end{array}$ & $\begin{array}{l}\text { Leick et al., } \\
1997\end{array}$ \\
\hline C. reinhardtii & $\begin{array}{l}\text { PK of the } \\
\text { mixed type }\end{array}$ & 48 & $\begin{array}{l}\text { PK is capable for autophos- } \\
\text { phorylation at serine and } \\
\text { tyrosine }\end{array}$ & No data & $\begin{array}{l}\text { PK is implicated in } \\
\text { fertilization }\end{array}$ & $\begin{array}{l}\text { Kurvari et al., } \\
\text { 1996; Shiu and } \\
\text { Li, } 2004\end{array}$ \\
\hline N. fowleri & PTK & No data & $\begin{array}{l}\text { PTK inhibitors blocked the } \\
\text { proliferation }\end{array}$ & No data & $\begin{array}{l}\text { PTK is implicated } \\
\text { in growth }\end{array}$ & $\begin{array}{l}\text { Chu et al., } \\
2000\end{array}$ \\
\hline E. histolytica & c-Src & 60 & $\begin{array}{l}\text { PTK is activated by FN bind- } \\
\text { ing with } \beta 1 E h F N R\end{array}$ & Paxillin & $\begin{array}{l}\text { PTK activates for- } \\
\text { mation of signaling } \\
\text { complex }\end{array}$ & $\begin{array}{l}\text { Talamas-Ro- } \\
\text { hana et al., } \\
\text { 1998; Hernan- } \\
\text { dez-Ramirez } \\
\text { et al., 2000; } \\
\text { Sengupta et } \\
\text { al., 2000, 2001; } \\
\text { Flores-Robles } \\
\text { et al., } 2003\end{array}$ \\
\hline E. histolytica & $\begin{array}{l}\text { FAK-like } \\
\text { kinase }\end{array}$ & 125 & $\begin{array}{l}\text { Is activated by collagen type I } \\
\text { and } \mathrm{Ca}^{2+} \text { stimulation }\end{array}$ & $\begin{array}{l}\text { Presumably the } \\
\text { STATs }\end{array}$ & $\begin{array}{l}\text { Is involved in trans- } \\
\text { duction of invasive } \\
\text { signal }\end{array}$ & $\begin{array}{l}\text { Cruz-Vera, et } \\
\text { al., } 2003\end{array}$ \\
\hline T. cruzi & PTK & 175 & $\begin{array}{l}\text { PTK is activated by stimula- } \\
\text { tion of membrane gp82 }\end{array}$ & No data & $\begin{array}{l}\text { Initiates host cell } \\
\text { invasion }\end{array}$ & $\begin{array}{l}\text { Yoshida et al., } \\
2000\end{array}$ \\
\hline T. brucei brucei & PTK & No data & $\begin{array}{l}\text { The PTK activity is stimulated } \\
\text { by IFN- } \gamma\end{array}$ & No data & $\begin{array}{l}\text { Stimulates prolif- } \\
\text { eration }\end{array}$ & $\begin{array}{l}\text { Mustafa et. al., } \\
1997\end{array}$ \\
\hline
\end{tabular}


this enzyme was shown (Mishra et al., 1999). At present it is known that these kinases as well as trypanosomatid kinases similar functionally with mammalian tyrosine kinases are not true tyrosine kinases. This conclusion is made based on analysis of kinomes of these protozoa. It is established that no genes coding PTK are present in their genomes (Ward et al., 2004). In these parasitic microorganisms, kinases similar functionally with mammalian tyrosine kinases are ascribed to the tyrosinelike group that includes enzymes related to those in the PTK, although they are serine-threonine protein kinases (Ward et al., 2004).

In the same way, stimulation of parasitic ameboflagellates Naegleria fowleri by human serum increased of tyrosine phosphorylation in proteins of relatively low molecular mass $(20,22,47,51$, and 53 $\mathrm{kDa}$ ) and decreased phosphorylation of proteins of higher molecular masses (70-250 kDa) (Chu et al., 2000). The increase of tyrosine kinase activity in the Naegleria fowleri cell lysates was observed after $5 \mathrm{~min}$, while the maximal phosphorylation of proteins at tyrosine, 15 min after addition of serum. Pretreatment of cell lysates with the inhibitor of tyrosine kinases genisteine significantly decreased phosphorylation in vitro of proteins at tyrosine (Chu et al., 2000). The importance of tyrosine phosphorylation during the life cycle of Trypanosoma brucei was proved for the first time by Marilyn Parsons and colleagues (Parsons et al., 1990; 1993). The authors demonstrated the appearance of tyrosine-phosphorylated proteins at 40-42 kDa during transition from slender to stumpy bloodforms. Other data indicate that phosphotyrosine-containing proteins with molecular masses of $34,50,82$, and $121 \mathrm{kDa}$ also occur in T. brucei (Mustafa et. al., 1997). Their phosphorylation was induced by interferon IFN- $\gamma$ (100 units $/ \mathrm{ml}$ ) stimulation. IFN- $\gamma$ induced a rapid and strong increase of tyrosine phosphorylation of several cellular proteins, which reached maximum after $5 \mathrm{~min}$ and was followed by a decrease to control levels after $120 \mathrm{~min}$. In vitro application of tyrosine kinase inhibitor tyrphostin A47 at a non-toxic concentration of $1 \mu \mathrm{M}$ to the trypanosome cultures caused a significant reduction of $\left[{ }^{3} \mathrm{H}\right]$ thymidine uptake by IFN- $\gamma$-stimulated trypanosomes. In animals, $1 \mathrm{mg}$ of the intraperitoneally injected tyrphostin A47 markedly reduced the parasite growth as compared with the vehicle dimethyl sulfoxide or the inactive compound tyrphostin A1. In conclusion, tyrosine kinases are strongly up-regulated in IFN- $\gamma$-stimulated $T$. brucei, and specific tyrosine kinase inhibitors can prevent trypanosome growth in vitro and in vivo (Mustafa et. al., 1997).

Yoshida et. al. (2000) reported involvement of Trypanosoma cruzi tyrosine kinase in the signal cascade that is initiated by a stimulation of glycoprotein gp82 and leads to mobilization of $\mathrm{Ca}^{2+}$ necessary for the onset of invasion. It was also found that the tyrosine kinase activity measured by the level of phosphorylation of protein of a molecular mass of $175 \mathrm{kDa}$ (p175) was induced in metacyclic $T$. cruzi forms by extracts of HeLa cells, in which parasites develop effectively, but not by extracts of K562 cells resistant to invasion. Treatment with genistein blocked phosphorylation of protein p175 and increased cytosol $\mathrm{Ca}^{2+}$ concentration.
In promastigotes Leishmania donovani, phosphorylation at tyrosine of proteins with molecular masses of 105 and $110 \mathrm{kDa}$ occurred at the first stage of invasion of the host cells. The heat shock induced by an elevation of temperature from $24^{\circ} \mathrm{C}$ to $37^{\circ} \mathrm{C}$ decreased the protein phosphorylation level at tyrosine in virulent, but not in avirulent parasite forms. This can indicate an important role of tyrosine phosphorylation in regulation of signal transduction at the initial stage of the host cells invasion (Salotra et al., 2000).

Tyrosine, serine, and threonine phosphorylation was studied in pro- and amastigote Leishmania mexicana forms, which was induced by insulin-like growth factor I (IGF-I) (Gomes et al., 1998). The phosphoamino acid analysis of patterns of the total and specific phosphorylation at tyrosine residues with use of labeled $\left[{ }^{32} \mathrm{P}\right]$-orthophosphate and immunoblotting with monoclonal anti-phosphotyrosine (anti-p-tyr) antibodies showed that stimulation of promastigote parasite forms with IGF-I induced tyrosine phosphorylation in protein of a molecular mass of $185 \mathrm{kDa}$, while stimulation of amastigote forms - phosphorylation at tyrosine of 40 and $60 \mathrm{kDa}$ proteins. Analysis of total amino acid phosphorylation revealed additional phosphoprotein sets: protein of a molecular mass of $110 \mathrm{kDa}$ in promastigotes and proteins of molecular masses of 120 and $95 \mathrm{kDa}$ in amastigotes. Besides, stimulation of the cells with IGF-I and stagespecific changes in levels of the total phosphorylation and of phosphorylation at tyrosine were found in leishmania throughout the entire life cycle. This indicates an important role of tyrosine phosphorylation in regulation of the leischmania cell morphogenesis.

In Entamoeba histolytica, a membrane protein of a molecular mass of $220 \mathrm{kDa}$ that had high level of tyrosine phosphorylation after interaction of $E$. histolytica trophozoites with fibronectin was revealed (HernandezRamirez et al., 2000). Earlier, these authors characterized protein of a molecular mass of $140 \mathrm{kDa}$ with the features of a $\beta-1$ integrin receptor that is associated with nonreceptor tyrosine kinases (Table 1 ) and collagen-binding protein (Talamas-Rohana et al., 1998). The presence of tyrosine kinases in amoebae was confirmed in immunoprecipitation reaction with a combined use of the specific substrate peptide RR-SRC, tyrosine kinase inhibitor genistein, and monoclonal anti-p-tyr antibodies (Hernandez-Ramirez et al., 2000; Sengupta et al., 2000, 2001). Interestingly, an amoeba non-receptor tyrosine kinase $\left(p p^{125}\right)$ is responsible for the amoeba STATs phosphorylation in response to collagen and calcium in E. histolytica trophozoites (Cruz-Vera et al., 2003). STAT amoeba homologues are involved in membrane-to-nuclei signaling and their tyrosine phosphorylation is essential for DNA binding and transcriptional enhancement.

Roisin et al. (2000) reported participation of tyrosine kinases in signal transduction in the protozoan parasite Toxoplasma gondii. The immunoblot analysis of tachyzoites lysate with anti-p-tyr 4G10 antibodies revealed tyrosine phosphorylation of several proteins in the range of 100-30 kDa. Phosphorylation of the 47 and $43 \mathrm{kDa}$ proteins was found to occur only after the $\mathrm{Ca}^{2+}$ release. When the tachyzoites were stimulated by $50 \mathrm{mM}$ $\mathrm{K}^{+}$that promotes $\mathrm{Ca}^{2+}$ influx into the cells, increased 
phosphorylation of two bands with an apparent molecular mass of 43 and $47 \mathrm{kDa}$ was observed. This work also was the first to experimentally substantiate the role of dual phosphorylation at tyrosine and threonine within microbial protein tyrosine kinases TXY sequence (like ERK1 and ERK2) after tyrosine phosphorylation stimulation by $\mathrm{Ca}^{2+}$ (Roisin et. al., 2000).

Whereas structure and functions of specific mammalian tyrosine kinases have been studied sufficiently well, information about structure and properties of PTK in unicellular organisms is significantly less complete. The biological role of tyrosine kinases in unicellular eukaryotes also seems less clear than in mammalian cells. The unicellular eukaryotes, whose genomes were sequenced, have no receptor tyrosine kinases, i.e. there is no EGFR homologue, IGFR homologue in yeast, trypanosomatids, and Malaria parasites. Similarly, most protists lack true cellular tyrosine kinases. They have the tyrosine-like group, that includes enzymes related to those in the PTK, although they are serine-threonine protein kinases.

\section{The role of the Ras subfamily proteins in signal transduction in unicellular eukaryotes}

The Ras subfamily proteins are small monomeric GTP-binding proteins that regulate signal transduction pathways activated by RTKs. The main function of Ras subfamily proteins in signaling in metazoan cells consists in triggering the pathway that controls growth and neuronal development in mammalian cells, eye development in Drosophila, and vulva development in C. elegans (Kayne, Sternberg, 1995; Wassarman et al., 1995). In these cascades, the Ras protein interacts directly with Raf kinase, one of the large group of MAP kinase kinases or MEKKs (Fig. 1). However, at present there is convincing evidence for interaction of Ras with a number of other downstream effectors (Shields et al., 2000), including phosphoinositide-3-kinase (PI3K) and Ral-GDS, a guanine nucleotide exchange factor (GEF) for Ral, another member of the Ras subfamily of proteins. Furthermore, it is now clear that signals are transmitted to the Ras-GEFs not only through the RTKs, but also through heteromeric $\mathrm{G}$ protein-coupled receptors (GPCR) (Reuther, Der, 2000).

In mammalian cells, all RTK ligands and receptors are coupled to activation of the Ras-MAPK pathways through recruitment of Grb2 and/or Shc and the Grb2-bound exchange factor Sos. The main adaptor protein Grb2 has SH2- and SH3-noncatalytic domains of Src-homology, which recognize phosphorylated tyrosine in growth factor receptors and signal molecules. The guanine nucleotide exchange factor Sos activates Ras by exchanging its GDP for GTP (Egan, Weinberg, 1993). Activated Ras is bound to the serine threonine kinase Raf-1 (MEKK), activates it, and thereby triggers the MAP kinase cascade (Moodie et al., 1993).

Most Ras proteins revealed in unicellular eukaryotes belong to the Rab and ARF subfamilies of the Ras family proteins and do not participate directly in the PTK-mediated signal transduction. On the other hand, few members of the Ras subfamily have been shown to be present in fungal and protozoan organisms and to be highly conserved.

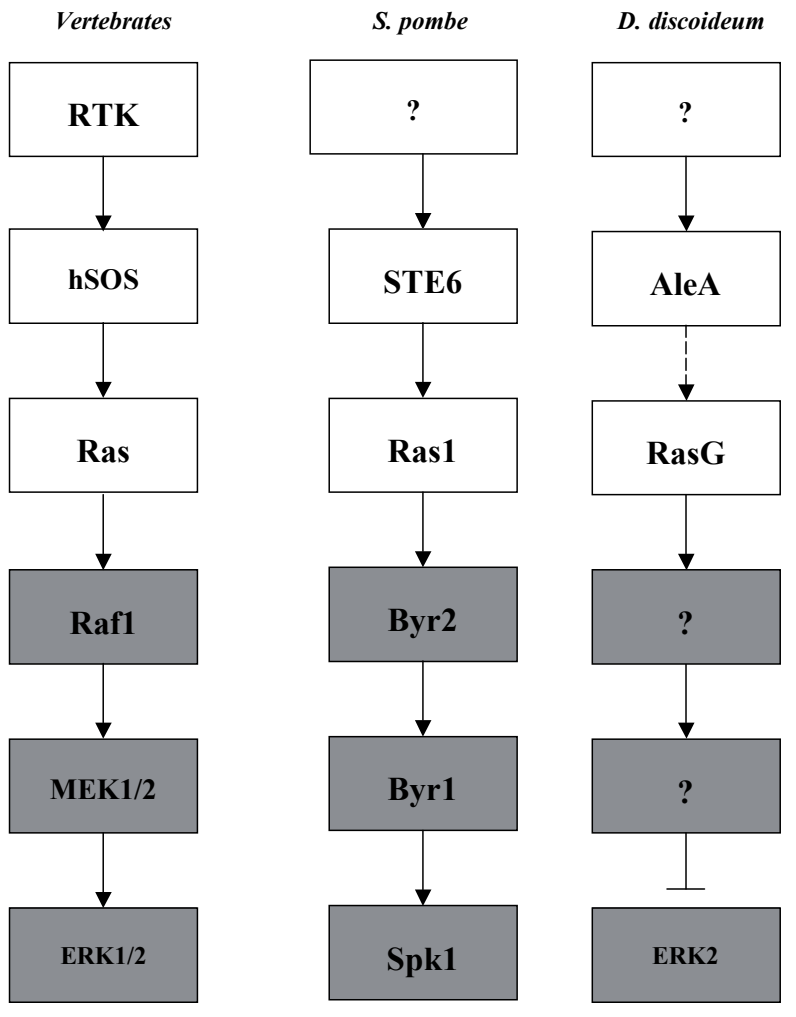

Fig. 1 Scheme of signal transduction via Ras-MAP kinase cascades in cells of vertebrates and unicellular eukaryotes. RTK- receptor tyrosine kinases; FAK- cytoplasmic tyrosine kinase; "?" - unidentified upstream or downstream targets within MAPK cascades; hSOS, STE6, AleA - guanine nucleotide exchange factors; Ras, Ras1, RasG - isoforms of small Gprotein of the Ras protein subfamily; Raf1, Byr2 - isoforms of MAPKKK; MEK1/2, Byr1 - isoforms of MAPKK; ERK1, ERK2, Spk1 - isoforms of MAPK. Gray color indicates kinases of the MAPK signaling cascades.

Members of the Ras subfamily have been found in yeasts Saccharomyces cerevisiae, Shizosaccharomyces pombe, Cryptococcus neoformans, Candida albicans, Ustilago maydis, Neospora crassa, Aspergillus nidulans, slime mold Dictyostelium discoideum and Physarum polycephalum, protozoa Entamoeba histolitica, Plasmodium falciparum, and Trypanosoma brucei (Shen et al., 1994; Thelu et al., 1994; Kosaka et al.; 1998; Fronk, 1999; Sowa et al., 1999; Jaffer et al., 2001). Structure of a number of Ras proteins from fungi and protozoa was determined and their coding genes were cloned. However, biological role of most known microbial Ras subfamily proteins has not yet been determined sufficiently clearly, as in the majority of unicellular eukaryotes the intermediate and final chains of the signal pathways, in whose activation these proteins participate, are not yet identified. Ras proteins were found in yeast, slime mold, and protozoa, but functional studies are relatively scarce. The functions of the microbial Ras proteins are divided into three general categories: regulation of growth, regulation of differentiation, and regulation of the actin cytoskeleton, - functions that are conserved in metazoans (Lim et al., 2003; Weeks, Spiegelman, 2003). The structure of the Ras pathways in these unicellular eukaryotes vary from microorganism to microorganism and especially from the conventional metazoan Ras-MAP kinase pathways. It is 
well known that in protists Saccharomyces cerevisiae, Candida albicans, Cryptococcus neoformans, Ustilago maydis, and Dictyostelium discoideum the Ras proteins activate adenylyl cyclase and that these cells expressing a constitutively activated Ras 1 protein produce higher levels of cAMP (Toda et al., 1984; Alspaugh et al., 2000; Lim et al, 2001).

Since the characterization of the microbial Ras proteins has made an important contribution to understanding of Ras protein function in the lower eukaryote PTK-signaling; these studies will be summarized in this section (Weeks and Spiegelman, 2003).

The first microbial ras genes to be described were those from the budding yeast Saccharomyces cerevisiae. They express two ras genes, ras1 and ras2, that encode proteins with nearly $90 \%$ homology to the first 80 positions of the mammalian Ras proteins, and nearly $50 \%$ homology to the next 80 amino acids (Powers et al., 1984). Monoclonal antibody against mammalian Ras proteins immunoprecipitated protein in yeast cells containing high copy numbers of the yeast ras2 gene. The authors also showed that the yeast Ras proteins, like the proteins encoded by the mammalian ras genes, terminated with the sequence cys $A A X$, where $A$ is an aliphatic amino acid. Thus, the yeast Ras proteins have the same overall structure and interrelationship as the family of mammalian Ras proteins (Powers et al., 1984). Functional studies demonstrated that yeast Ras proteins participated in regulation of growth (Tatchell et al., 1984; Wigler et al., 1988). S. cerevisiae, containing disruptions of either of two genes were viable, but haploid yeast spores carrying disruptions of both genes failed to vegetative grow (Kataoka et al., 1984; Tatchell et al., 1984). A loss of function mutation in either ras1 or ras 2 has no effect on growth in glucose, whereas a loss of function of both genes (rasl/ras2 null cells) causes arrest in the $G$ phase of the cell cycle (Tatchell et al., 1984). Ras2 is expressed in appreciably larger amounts than Rasl (Mosch et al., 1999) and overexpression of Ras1 completely suppresses the failure of ras 2 null cells to grow on non-fermentable carbon sources (Tatchell et al., 1985). The Ras proteins activate adenylyl cyclase and cells expressing a constitutively activated Ras protein produce higher levels of cAMP (Toda et al., 1985). The regulation of adenylyl cyclase by Ras involves both its direct binding to the enzyme and the participation of the adenylyl cyclase-associated protein, Srv2p (Shima et al., 2000). Ras is activated by the GEF, Cdc25, with cdc25 null cells that have the same defective growth phenotype as ras1/ras2 null cells (Robinson et al., 1987) and are inactivated by the GTPase activating proteins (GAPs), Ira1 and Ira2 (Tanaka et al., 1990). In S. cerevisiae cAMP activates the cAMP dependent protein kinase A (PKA) and $\mathrm{ras} /$ /ras2 null strains are suppressed either by a disruption in the gene encoding the negative regulatory subunit of PKA or by overexpression of a catalytic subunit of PKA. In addition to regulating progression through $G_{1}$ the Ras-PKA pathway is a negative regulator of the stress response. Thus, for example, cells expressing an activated ras allele are less successful at surviving nitrogen starvation or heat shock (Kataoka et al., 1984,
Nikawa et al., 1987). Recently, several new targets of the stress-activated Ras-PKA pathway have been discovered. These include the Msn2 and Msn4 transcription factors mediating a part of induction of STRE-controlled genes by a variety of stress conditions, the Rim 15 protein kinase involved in stationary phase induction of a similar set of genes and the Pde1 low-affinity cAMP phosphodiesterase that specifically controls agonist-induced cAMP signaling (Thevelein and Winde, 1999).

Diploid S. cerevisiae exhibit filamentous growth (pseudohyphal growth) in response to either nitrogen starvation or an excess of a fermentable carbon source (Gimeno et al., 1992). The ras2 null cells lose the filamentous growth phenotype and two parallel signaling pathways that involve Ras 2 have been implicated. One of these is a MAP kinase cascade that uses some of the kinase components responsible for Ras-independent haploid cell mating. However, during pseudohyphal growth, the MAP kinase cascade in $S$. cerevisiae is triggered by signals transmitted from Ras through the RHO (Rho) subfamily protein Cdc42, either of two 14-3-3 proteins, Bmhl and $\mathrm{Bmh} 2$, and the Ste20 protein kinase (Mosch et al., 1996; Mosch and Fink, 1997; Roberts et al., 1997). It is interesting that in mammals the GTP-bound Rho also can regulate the stress-activated p38- and JNK-MAPK pathways. The latter pathway that regulates pseudohyphal growth involves a GPCR, Gprl, a $\mathrm{G} \alpha$ protein, Gpa2, Ras, ACA, and PKA (Kubler et al., 1997; Lorenz et al., 2000). Activation of PKA by mutations in the bcy1 gene that encodes the PKA regulatory subunit induces filamentous growth in both wild type cells and in strains deficient in components of the MAP kinase pathway (Pan and Heitman, 1999; Rupp et al., 1999). These results indicate that PKA activation is sufficient to trigger filamentous growth.

Ras 2 is also essential for the haploid invasive growth that occurs after prolonged incubation on rich media, possibly in response to metabolic by-products (Mosch et al., 1999; Stanhill et al., 1999). Overexpression of Rasl can rescue the invasive growth defect of haploid ras 2 null cells, indicating that there is insufficient Rasl present in a ras2 null cell lo allow invasive growth (Mosch et al., 1999). Haploid invasive growth can be induced by either the Ras dependant MAP kinase cascade or the Ras dependent PKA pathway (Mosch et al., 1999; Roberts and Fink, 1994).

S. cerevisiae also has a single ras-related rap gene, rsr1, and its deletion disrupts the normal pattern of bud site selection during normal haploid growth (Bender and Pringle, 1989). Rsr1 is highly concentrated at the incipient bud site in the plasma membrane and is essential for the co-localization of Cdc42 (Park et al., 2002). Although the Ras proteins and Rsr1 clearly have independent functions, Rsr1 is capable of substituting for Ras function when overexpressed in ras1/ras $2 /$ cyr1 null cells. It has been speculated that, in addition to Ras2, Cdc42 and Bmh1/2 could also be involved in regulation of cytoskeletal polarity during temperature stress in haploid cells (Ho and Bretscher, 2001).

The Ras-mediated MAP kinase cascade also has been described in yeast $S$. pombe, C. albicans, and $C$. 
neoformans and possibly in U. maydis and S. cerevisiae (Zhang et al., 2001; Weeks, Spiegelman, 2003). However, at present there is evidence that only in $S$. pombe RasMAPK the pheromone response pathway is clearly analogous to the Ras-activated MAP kinase cascade in mammalian cells (Hughes et al., 1993). In the S. pombe, Ras 1 is activated by stimulation of the GEF activity (STE6), this resulting in the consecutive activation of Byr2 (MEKK), Byr1 (MEK), and Spk1 (MAP kinase) (Fig. 1). The Byr1 is dual protein kinase that phosphorylates Spk1 at both tyrosine and threonine residues in the subdomain VIII of the protein. Phosphorylation of both amino acids has been shown to be essential for Spk1 function. In turn, action of this kinase is to activate phosphorylation transcription factors, which leads to altered gene expression.

Ras1 may also stimulate a signal pathway involved in cell morphogenesis (Chang et al., 1994; Hughes, 1995). The ras 1 null cells $S$. pombe exhibit abnormal cell shape and the absence of polarized cell growth, phenotypes shared with scd1 mutants. Ras1 interacts with Scd1, a putative GEF for Cdc42 (Chang et al., 1994). Since ras1 null cells exhibit disorganized cytoskeletal structures, it has been speculated that Ras 1 is a part of the complex that regulates actin and microtubule assembly (Hughes, 1995). Two-hybrid interaction analysis has implicated downstream components of the Ras1-Scd1 pathway in regulation of formation of the mitotic spindle, a microtubule structure (Li et al., 2000). The second RasGEF, Efc25, has recently been characterized (Papadaki et al., 2002). This protein also regulates the Ras1-Scd1 pathway, but not the Ras1-Byr2 MAPK pathway. Thus, in the S. pombe three GEFs, STE6 and Scd1 or Efc25, activate two these distinct downstream pathways regulated by Ras 1 .

Rasgenes were isolated from the slime mold Physarum polycephalum (Kozlowski et al., 1993), Dictyostelium minutum (Van Es et al., 1997) and Dictyostelium discoideum (Reymond et al., 1984, Robbins et al., 1989, 1990; Daniel et al., 1994). The Ras proteins play an importance role in the life cycle of these microorganisms, but functional studies have been performed only on $D$. discoideum; so only the Ras proteins of this latter species will be discussed.

In the $D$. discoideum six ras subfamily genes, ras $G$, $\operatorname{ras} D$, ras $B$, ras $C$, ras $S$ and $\operatorname{rap} A$, have been thus far partially characterized (Reymond et al., 1984; Daniel et al., 1994). Only two of the encoded products, RasG and RasD, are highly related to each other and are the $D$. discoideum proteins most related to mammalian Ras. RasB. RasC and RasS are somewhat divergent from each other and from RasG and RasD (Daniel et al., 1994). The Rapl protein is $76 \%$ identical to human Rapl, suggesting that they are homologues.

ras $D$, the first Dictyostelium ras gene to be described, was originally isolated as a prestalk cell enriched mRNA species from developing cells (Reymond et al., 1984). It is expressed at very low levels in vegetative cells, but expression increases dramatically during late aggregation. RasG was isolated from a clonal library, using the rasD gene as a probe (Robbins et al., 1989). It is expressed during growth and early development, but expression declines rapidly as development progresses. The expression of activated ras $G$ in prespore cells results in their transdifferentiation into prestalk cells (Jaffer et al., 2001).

Transformants overexpressing a consiitutively activated form of RasD, from the ras $D$ promoter, produce multi-pletipped aggregates that do not develop further (Weeks and Spiegelman, 2003). These transformants exhibit enhanced expression of prestalk cell specific genes (Louis et al., 1997). Surprisingly, rasD gene disruption caused no change in cell type determination (Wilkins et al., 2000). The only observable defect of ras $D$ null strains is a near total loss of the phototactic and thermotactic properties of the slugs. Since ras $D$ expression is enriched in the prestalk cell populations in the anterior region of the slug (Esch and Firtel, 1991), it is plausible that RasD is involved in modulation of sensory signaling from the photo- and thermoreceptors that are presumably localized at the anterior tip of the slug (Fisher, 1997). Although ras $G$ expression decreases during development, there are still appreciable levels of the protein present during aggregation and it is possible that RasG substitutes for cell type determination functions of RasD in rasD null cells.

RasG is the major Ras species in vegetative cells $D$. discoideum and expression of constitutively activated RasG during vegetative growth results in cells that fail to aggregate, due to a reduced capacity to generate cAMP (Khosla et al., 1996), rasG gene disruption results in cells that exhibit a complex phenotype. Vegetative rasG null cells have aberrant lamellipodia, multiple elongated filopodia, and unusual punctate polymerized actin structures (Tuxworth et al., 1997). The cells exhibit reduced motility and polarity. They grow more slowly and to a much lower final density than the parental wildtype cells in suspension culture and are multinucleate, suggesting a problem in cytokinesis. It is interesting that both the disruption of the ras $G$ gene and the expression of constitutively active RasG inhibit growth, motility, and chemotaxis, suggesting that a precise level of signaling is necessary (Tuxworth et al., 1997).

In rasG null cells, levels of RasD protein are substantially increased and expression of RasD under the control of the ras $G$ promoter rescues all adverse consequences of rasG gene disruption, except for the motility defect (Khosla et al., 2000). The combined loss of RasG and RasD may be lethal, since attempts at isolating ras $G /$ ras $D$ double gene disruptants have been unsuccessful. RasG appears to negatively regulate vegetative cell expression from several of the ras gene promoters. Thus, the levels of the various Ras proteins are tightly regulated in vegetative cells $D$. dictyostelium (Khosla et al., 2000).

RasG appears to negatively regulate ERK2, a MAP kinase that is activated in response to CAMP and is required for accumulation of cAMP (Segall et al., 1995). The cAMP stimulation of phosphorylation of ERK2 is enhanced in rasG null cells and reduced in cells overexpressing activated RasG (Kosaka et al., 1998). Cells lacking ERK2 fail to aggregate (Segall et al., 1995; Wang et al., 1998) and a disruption of the regA gene, encoding a phosphodiesterase, rescues this defect. A plausible explanation for these results is that phosphorylated ERK2 inhibits the phosphodiesterase activity of RegA (Shaulsky et al., 1998), thereby resulting in cAMP accumulation and 
PKA activation (Loomis, 1998). In cells overexpressing activated RasG, a reduction in phosphorylated ERK2 could result in insufficient cAMP accumulation to fully activate PKA, erkB null cells form few spores, suggesting a requirement for ERK2 for the expression of prespore cell specific genes (Gaskins et al., 1996) and the developmental expression of activated RasD also results in down-regulation of prespore cell specific gene expression (Louis et al., 1997; Jaffer et al., 2001).

$\mathrm{Ras} \mathrm{C}$ is necessary for cAMP relay during aggregation $D$. discoideum, so that the activation of adenylyl cyclase (isoform ACA), in response to CAMP, is reduced to a negligible level in rasC null cells (Lim et al., 2001). However, addition of GTP $\gamma S$ to extracts of ras $C$ null cells, which bypasses the need for cAMP binding to cARI, results in a partial stimulation of ACA activity (Lim et al., 2001). These results place RasC upstream of $G \alpha 2 \beta \gamma$ in mediating activation of ACA. Analysis of the cAMP binding to cell membranes following GTP $\gamma S$ addition, as a measure of $\mathrm{G} \alpha 2 \beta \gamma$ dissociation (Kumagai et al., 1991), is consistent with the idea that RasC may be involved in regulating $G \alpha 2 \beta \gamma$ dissociation (Weeks and Spiegelman, 2003).

In addition to its requirement for cAMP relay, RasC is also clearly involved in regulation of vegetative growth (Kae et al., 2004) and chemotaxis (Wessels et al., 2004). During the early phase of aggregative development, rasC null cells exhibit reduced polarization and chemotaxis poorly in a spacial cAMP gradient relative lo wild type cells, whereas cAMP pulsed ras $C$ null cells exhibit increased polarization and chemotaxis more rapidly relative to wild type cells (Lim et al., 2001). However, despite this apparent enhanced chemotactic ability in a spatial cAMP gradient, these cells do not respond to a simulated temporal gradient of cAMP.

The phosphorylation of protein kinase $B(P K B)$ and its polarized translocation to the membrane in response to cAMP has been implicated in the chemotactic response (Meili et al., 1999; Firtel and Chung, 2000). Although PKB phosphorylation is significantly reduced in ras $C$ null cells upon cAMP stimulation (Lim et al., 2001), PH-domains of PKB are successfully translocated to the plasma membrane of cAMP stimulated ras $C$ null cells. It appears, therefore, that RasC is not necessary for generation of $\mathrm{PH}$-domain recruitment sites, although a contributory role cannot be totally ruled out. Since PKB phosphorylation in response to cAMP is also reduced in ras $G$ null cells and RasG interacts with PI3-kinase in a yeast two hybrid assay (Lee et al., 1999), it is possible that both RasC and RasG independently contribute to the regulation of PKB activity and translocation, via the PI3-kinases. Mutants disrupted in both ras $C$ and rasG might exhibit a more severe chemotaxis defect.

Possible signaling partners of RasG and RasC include RIP3, identified as a Ras-interacting protein in a yeast two-hybrid screen (Lee et al., 1999), and the RasGEF AleA (Insall et al., 1996; Lim et al., 2001). Both rip3 and aleA null cells exhibit defects in cAMP relay and there is a partial stimulation of ACA activity in their cell lysales (Lee et al., 1999; Lim et al., 2001), suggesting the coordinate involvement of RasC, Rip3, and AleA in a pathway that regulates $\mathrm{G} \alpha 2 \beta \gamma$ function. ERK2 phosphorylation is upregulated in response to a cAMP stimulus in ale $A$ null cells (Aubry et al., 1997; Lim et al., 2001), a response similar to that observed in rasG null cells. It is possible, therefore, that AleA and Rip3 regulate activities of both RasC and RasG.

Disruption of the rasS gene results in cells that fail to grow under axenic conditions, which correlates with a dramatic impairment in fluid phase endocytosis and a reduced number of the crown-like morphological structures that mediate macropinocytosis (Chubb et al., 2000). These rasS null cells also exhibit a three-fold enhancement of motility relative to the parental strain. It has been suggested that there is competition for the recruitment of cytoskeletal organizing proteins, such as coronin and myosin I between the endocytic cups and the pseudopodia, which would limit the ability of cells to stimulate both endocytosis and movement at the same time. Hence, RasS may regulate the balance between feeding and movement (Chubb et al., 2000). rasS null cells differentiate normally, indicating that RasS is not required for the differentiation process.

In protozoan organisms the Ras subfamily proteins were found only in Entamoeba histolitica, Plasmodium falciparum, and Trypanosoma brucei. In the E. histolitica, genes homologous to the ras and rap (Krev-1) were cloned (Shen et al., 1994). Two putative ameba ras genes (Ehras1 and Ehras2) that contain 205 and 203 amino acid (aa) open reading frames (ORFs), respectively, were identified. The Ehras 1 ORF shows a $91 \%$ positional identity with that of Ehras2, a $55 \%$ identity with Dictyostelium discoideum $(D d)$ ras, and a $47 \%$ identity with human $(H s)$ ras. The Ehrap1 ORF shows a $93 \%$ positional identity with that of Ehrap2, a $60 \%$ identity with Dd rap, a $61 \%$ identity

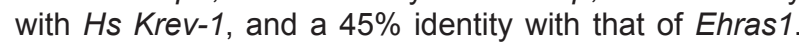
Conserved aa in each ameba ras and rap ORF include GTP-binding sites, effector site, site of ADP-ribosylation by Pseudomonas exoenzyme $\mathrm{S}$, and $\mathrm{COOH}$-terminus CAAX. A single 21-kDa ameba Ras protein reacted with the rat Y13-259 anti-ras monoclonal antibody located on the cytosol side of the plasma membrane. These were the first ras and rap genes identified from protozoan parasites. A gene has been identified in the T. brucei, and the encoded product is equally related to the Ras and Rap proteins of E. histolitica. This suggests that this gene is possibly an evolutionary ancestor of both ras and rap genes of other eukaryotes (Sowa et al., 1999). The Ras proteins identified in protozoan microorganisms are present during all stages of the life cycle, but their role in signal transduction is not yet clear.

Thus, the signaling pathways regulated by Ras proteins in mammalian and microbial cells differ functionally and structurally. The most intensively studied microbial Ras subfamily members activate adenylyl cyclase and are involved in Ras-PKA pathways; only in few eukaryotic microorganisms, Ras proteins are involved in Ras-MAPK signaling that have great similarity with such in mammals. This suggests that in evolution of the eukaryotic organisms the Ras proteins originally participated in regulating cAMP-dependent signal pathways and their role in the MEKK-MEK-MAPK module stimulation is connected with transition from unicellularity to multicellularity. 
The MAPK signaling cascades in unicellular eukaryotes

In mammalian cells, tyrosine phosphorylation is rapidly and sequentially translated to changes in phosphorylation of protein serine/threonine MAP kinases (MAP3Ks and MAP2Ks). The latter are highly specific for the downstream components ERK-1 and ERK-2 MAPKs. Activation of these kinases results from phosphorylation of threonine and tyrosine residues in a TXY-motif that is common to most MAPKs. MAP kinases activate several regulatory proteins in the cytoplasm and in the nucleus to initiate such cellular processes as proliferation, differentiation, and development (Seger and Krebs, 1995).

As soon as mammalian MAP2K (MEK) and MAPKs had been cloned, they were noticed to have sequence homology to yeast signal transduction kinases that are sequentially activated in response to extracellular stimuli. Later on, data appeared that the MAPK that have a TXY-motif were also present in other unicellular eukaryotes. In this connection, it is interesting to compare the microbial MAP kinase signaling cascades with those in vertebrates. This will allow better understanding the functional role of tyrosine phosphorylation in regulation of signal transduction MAP kinase pathways and specifying significance of individual MAPK components that are common to all eukaryotes.

In Saccharomyces cerevisiae, several different MAPK cascades exist, i.e. multiple sets of similar enzymes form distinct pathways that are activated by different external signals (e.g., mating pheromone, cell wall integrity, and osmolarity changes (Figs. 2 and 3). The diversity and function of MAPKs in yeast have been the subject of several excellent reviews (Errede and Levin, 1993; Neiman, 1993; Ammerer, 1994; Herskowitz, 1995; Elion, 2000). In the current review we will concentrate on the signaling pathways that use MEKK, MEK and yeast MAPK isoforms that appear to be the principal ones in mammalian growth factor signaling.

The yeast MEKK-MEK-MAPK cascades regulate at least six functionally different signal pathways. They govern transitions in its life cycle - mating and invasiveness in haploid strains and pseudohyphal development and spore formation in diploid strains - as well as maintenance of cells at a high osmolarity (Herskowitz, 1995). Studies of these different pathways provide a great amount of information on different possible inputs to MEKK-MEK-MAPK modules, from two-component system, SH3-domain sensor protein Sho1p, G protein-coupled receptors and $\mathrm{PKC} 1$ and to new components that play important roles

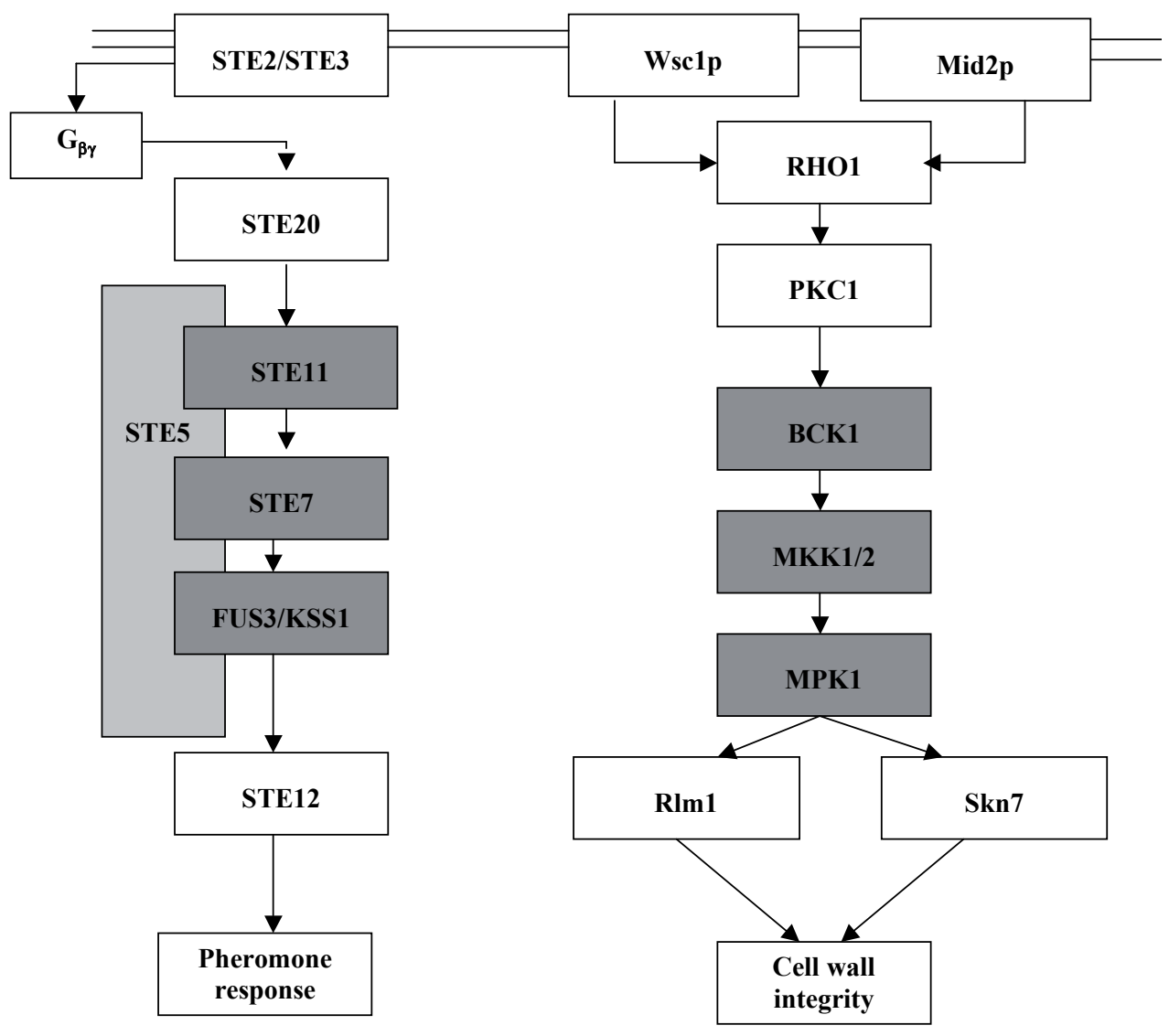

Fig. 2 The MAPK of S. cerevisiae activated by G-protein-coupled receptors STE2/STE3 and PKC1. STE2/STE3 - serpentine G-protein-coupled receptors for pheromones; Wsclp, Mid2p - membrane sensors; RHO1 - small G-protein; G $\beta \gamma$ (STE4) - $\beta \gamma$-subunit of heterotrimeric G-protein; STE5 - scaffold protein; STE20 - PAK-like kinase; STE11, BCK1 - MEKK homologues; STE7, MKK1/2 - MEK homologues; FUS3, KSS1, MPK1 - MAPK homologues; STE12, RIml, Skn7 - transcription factors. Dark gray shading indicates kinases of the MAPK signaling cascades. Light gray shading indicates scaffold protein. 


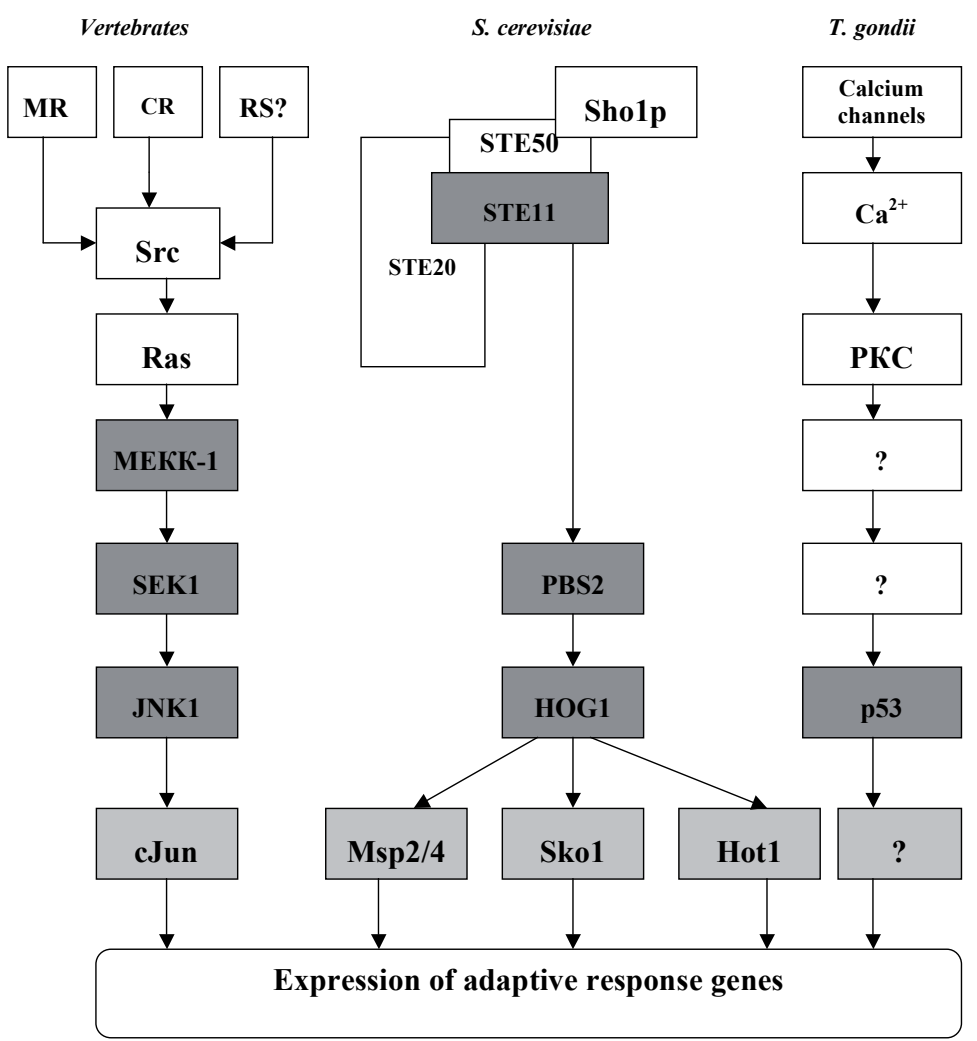

Fig. 3 Stress-activated MAP kinase cascades in vertebrates and unicellular eukaryotes. MR - mechanoreceptors; CR - cytokine receptors; RS - suggested redox-sensitive sensors; OS - suggested osmosensors; Src - non-receptor tyrosine kinases; PKC - protein kinase C; (?) - unidentified targets; $\mathrm{Ca}^{2+}$ - calcium ions; Ras - small G-protein; Sho1p - SH3-containing osmosensor protein; STE20 - PAK-like kinase; STE50 - subunit of STE11 kinase. MEKK-1, SEK1, JNK1, PBS2, HOG1, p53 - kinases of stress-activated MAP kinase cascades. c-Jun, Msp2/4, Sko1, Hot1 - factors of transcription. Taupe colour - kinases of the MAPK signaling cascades; light gray - transcription factors. Details in the text.

in the MEKK-MEK-MAPK module and are likely to be found in mammalian cells. Here we will consider only two MAP kinase cascades $S$. cerevisiae. One of them, the well-studied MAPK module of the pheromone response pathway is involved in mating and other steps in their yeast life cycle, and is interesting in that it is activated through serpentine $G$ protein-coupled receptors STE2/STE3 by the mechanism that is partially similar to that in the higher eukaryote cells (Herskowitz, 1995). The other cascade is responsible for cell wall integrity and is activated by PKC1 (Blumer et al., 1994), as well as by several mammalian signaling cascades (Seger and Krebs, 1995). Only in the pheromone response pathway and in the PKC1 pathway the $S$. cerevisiae have complete MAPK cascades with identified MEKK, MEK, and MAPK.

Unlike mammalian, Drosophila, and nematode cell systems with their Raf-MEK-MAPK module, in which MEK activity can be stimulated by activating a RTK to lead to activation of the protein kinase Raf, this MEKK cascade activity in S. cerevisiae that lacks RTK and Raf is controlled ultimately by serpentine $G$ protein-coupled receptors.

A typical example of signal transduction to the yeast MAPK cascade with participation of serpentine receptors can be the pheromone response pathway. This response pathway is necessary for haploid strains of yeast that are of the mating type a or $\alpha$ to mate with each other. There are three major responses: transcriptional induction of genes involved in mating, arrest of cells in $G_{1}$, and morphological changes. Each of the haploid cell types produces a peptide mating pheromone, a factor or $\alpha$ factor, that acts on the serpentine receptors of its mating partner. The a cells produce the $\alpha$ factor receptor STE3, whereas the $a / \alpha$ cells produce none. Synthesis of the receptor is governed at the transcriptional level by cell type-specific regulatory proteins; all intracellular components of the pheromone response pathway are common to the a and $\alpha$ cells (Herskowitz, 1995).

Activation of the receptor-caused dissociation of $\mathrm{G} \alpha$ from $G \beta \gamma$ of heterotrimeric $G$ protein then activates the MAPK cascade in an as yet unknown manner involving STE20 and STE5. STE5 acts as a scaffold for the MAPK cascade and is not associated with G $\beta$ (STE4), STE20 or STE12, but is associated with STE11 and STE7, as well as with MAPKs, FUS3, and KSS1. These results lead to suggestion that STE5 acts as a scaffold for the MAPK module (Fig. 2).

STE11, a MEKK family member, then phosphorylates and thereby activates STE7, a MEKfamilymember(Neiman and Herskowitz, 1994). STE7, in turn, phosphorylates the MAPKs FUS3 and KSS1 and activates them (Gartner et al, 1992; Errede et al., 1993). The activated MAPKs then apparently activate the transcription factor, STE12, by phosphorylating it (Elion et al., 1993). STE12, often in association with the general transcription factor MCM1, then activates transcription of numerous genes coding for components of the pheromone response pathway itself and genes necessary for cell fusion. Cell cycle arrest in 
response to the mating pheromones results ultimately from action of the FAR1 protein that binds to cyclinedependent kinases CDC28-CLN1 and CDC28-CLN2 to inhibit their activity (Peter and Herskowitz, 1994).

Biochemical studies have shown that FUS3, in addition to FAR1 and STE12, has several other substrates, including STE7 (Zhou et al., 1993) and STE5 (Kranz et al., 1994); however, their functional significance is unknown: they might play a role in down-regulation of the pathway or in activation of the pathway. Answer to this question needs further investigations.

Signal transmission from growth factor receptors in mammalian cells to the MAP kinase cascade might include not only participation of RTK and GPCR, but also PKC-activating mechanisms. These have not yet been sufficiently studied; they include multiple levels of a crosstalk existing between the both signal systems at early points during signal events. Therefore, it is particularly interesting to consider the direct way of the extracellular signal transmission with participation of PKC1 (isoform of PKC) onto the MAP kinase cascade (MEKK-MEK-MAPK) in yeasts.

In $S$. cerevisiae, like in some other eukaryotic organisms (Figs. 2 and 3), PKC1 participates in regulation of stress-activated signal transduction pathways. Mutants lacking PKC1 (gene encoding yeast PKC1) at all temperatures has a cell lysis defect that can be suppressed by a high-osmolarity medium (Levin and Bartlett-Heubusch, 1992; Paravicini et al., 1992).

These components of the PKC1 pathway have been identified by isolation of supressors, in particular, the high copy plasmid suppressors that restore growth in mutants defective in different components of this pathway (Lee and Levin, 1992; Irie et al., 1993; Lee et al., 1993; Errede et al., 1995). These studies have led to identification of genes for a MEKK homolog, $B C K 1$, a MEK homolog, MKK1, and a MAPK homolog, MPK1. The MKK1 gene has turned out to be functionally redundant with a related gene, MKK2 (Irie et al., 1993). Mutants lacking any of these components - the MEKK (bck1), two MEKs ( $m k k 1$ and $m k k 2)$, or the MAPK (mpk1) showed the same phenotype: lysis at a high temperature. Since the phenotype of mutants deleted for PKC1 is more severe than for defective mutants, it is suggested that PKC1 controls a bifurcated pathway, one arm of which contains the MAPK cascade (Lee and Levin, 1992). Upstream components that could control PKC1 include the putative membrane sensors Wsc1p and Mid2p (Ketela et al., 1999) as well as the RHO1 small G-protein (Nonaka et al., Qadota et al., 1996) (Fig. 2).

By the present time it is established that the $S$. cerevisiae PKC1 is an activator of the MAP kinase cascades that perform transmission of signals inducing the cell processes that are aimed not only at maintenance of the cell wall construction (Lee, Levin, 1992; De la TorreRuiz et al., 2002; Krause and Gray, 2002; Reinoso-Martin et al., 2003), but also at polarized growth (Philip and Levin, 2001) and adaptation (Kamada et al., 1995, Ketela et al., 1999). Interestingly, in the closely related species S. pombe the $\mathrm{Pkc}_{\mathrm{p}} \mathrm{p}$ and $\mathrm{Pkc} 2 \mathrm{p}$ that have a high degree of structural homology with the $S$. cerevisiae PKC1 did not transmit signals to the MAP kinase cascade (Perez and Cthroughe, 2002). Both PKC forms in these yeasts also are involved in regulation of processes of cellular integration, but mediate their action through reaction of biosynthesis of the cell wall polymer $(1 \rightarrow 6)$ - $\beta$-glucan with participation of the enzyme (1-3)- $\beta$-D-glucansynthase (Arellano et al., 1999).

In other model eukaryotic microorganisms, no complete MEKK-MEK-MAPK modules have been revealed so far. However, they were found to contain integral MAP kinases phosphorylated at tyrosine and threonine, which indicates a great importance of the activated MAP kinases for down-regulation of cellular events.

In the slime mold Dictyostelium discoideum the MAP kinase ERK2 has been shown to be essential for growth and to play a role in multicellular development (Gaskins et al., 1994). Overexpression of ERK2 in D. discoideum results in abnormal slug morphogenesis and fruiting body formation. In addition, ERK2 in D. discoideum is important for receptor-mediated stimulation of adenylyl cyclase ACA and is required for accumulation of intracellular cAMP (Segall et al., 1995; Maeda et al., 1996; Aubry et al., 1997; Kuwayama et al., 2000). Activation mechanisms in MAPK signaling in $D$. discoideum are not yet completely clear. The cAMP acting through serpentine cAMP receptors is known to produce a rapid and transient stimulation of the $D$. discoideum ERK2 activity (Maeda and Firtel, 1997). This might indicate that the $D$. discoideum ERK2 can be activated by $\mathrm{G}$ protein-coupled receptors by the mechanism that is similar with that in the higher eukaryotes. The MAP kinase cascade in $D$. discoideum is a part of the complex signal pathway required for cell aggregation. This pathway includes RasGEF AleA and RasG (Fig. 1) that are important regulators of ERKs activation and adaptation. By examining both the level and kinetics of activation and adaptation of ERK2, it was shown that Ras was a negative ERK2 regulator. Activation of Ras or disruption of the RasGAP gene resulted in reduced ERK2 activation, whereas disruption of putative RasGEF or expression of dominant negative Ras proteins (which are described in detail in the preceding Section) have a more rapid, higher, and extended activation. Moreover, the constitutive expression of a PKA catalytic subunit was shown to bypass the requirement of ERK2 for aggregation and later development, indicating that PKA lies downstream from ERK2 and that ERK2 may regulate one or more components of the signaling pathway required for mediating the PKA function (Aubry et al., 1997).

Recently, MAP kinases and genes encoding microbial MAPK in parasitic fungi Fusarum oxysporum (Di Pietro et al., 2001), in protozoan organisms Plasmodium falciparum (Doerig et al., 1996; Lin et al., 1996; Graeser et al., 1997), Toxoplasma gondii ( $\mathrm{Ng}$ et al., 1995, 1997; Roisin et al., 2000), Tetrahymena thermophila and Tetrahymena pyriformis (Nakashima et al, 1999), Trypanosoma brucei (Hua and Wang, 1994, 1997), and Leishmania mexicana (Wiese, 1998) have been identified. These kinases contribute to amplification and specificity of transmitted signals in the nucleus to initiate cellular processes, such as growth, development, and morphogenesis. However, identity of these kinases is not known. Certainly, they lack transcriptional regulation and the mechanisms, by which proliferation is regulated in protozoan and metazoan 
cells, are different. Many of them do have multiple protein kinases similar to MAPKs, but for the most part their roles are not yet established.

MAP kinase of $T$. gondii has several forms (Roisin et al., 2000). It is interesting that when using antibodies to the mammalian ERK active forms recognizing only MAP kinases phosphorylated at tyrosine and threonine, not two activated MAP kinases usually detected by these antibodies, but six, of molecular masses of 43 , 45, 47, 53, 67, and $80 \mathrm{kDa}$, were found in T. gondii. An immunoblot analysis with the use of anti-ERK1 and anti-ERK2 antibodies revealed several immunoreactive bands at $57,53,47$, and $43 \mathrm{kDa}$. Based on similarity of molecular weights and kinase activities with mammalian MAP kinases, the p47 and p43 protein were identified as homologues of ERK1 and ERK2, respectively. The p53 protein revealed by specific anti-SAPK antibody can correspond to p54-JNK2/SAPK, while the p57 band detecting anti-ERK antibodies, but not forming immune complexes with antibody to the active ERK form might presumably be an inactive isoform of the ERK homologues (Roisin et al., 2000) or the MAP kinase that, like ERK3, is not activated by phosphorylation at tyrosine and threonine residues inside the TXY-motif (Boulton et al., 1991). The p67 band, phosphorylated myelin basic protein (MBP), was also detected with the anti-active ERKs antibodies, suggesting that this protein contains the TXY motif and seems to be an ERK7 homologue (Abe et al., 1999). The nature of the redox-sensitive p80 kinase of $T$. gondii has not been yet elucidated. The p80 protein detected using the anti-active ERK antibodies was activated in response to $\mathrm{H}_{2} \mathrm{O}_{2}$, which suggests that the $\mathrm{p} 80$ can be a homologue of the mammalian ERK5 (Abe et al., 1996). The large spectrum of the revealed MAP kinase isoforms in $T$. gondii indicates an important role of these enzymes in coordination of many cellular processes.

A MAPK homologue of Plasmodium falciparum, PfMAP (also known as Pfmap-1), was simultaneously discovered independently in three laboratories (Doerig et al., 1996; Lin et al, 1996; Graeser et al., 1997). It was shown that, like other MAP kinases, it contained a TXYmotif in the kinase subdomain VIII, whose phosphorylation at tyrosine and threonine is essential for activity (Robbins et al., 1993; Graeser et al., 1997). Use of immunoblot analysis and immunopreciptation reaction has allowed revealing in $P$. falciparum four different MAP kinase forms: p40, p80, p100, and p150 (Lin et al, 1996, Graeser et al., 1997). The total MAP kinase activities increased in the process of parasite maturation (Graeser et al., 1997). Activity of the $\mathrm{p} 80$ kinase was high at the asexual stage of parasite development, whereas the p100 protein activity, on the contrary, in gametes and zygote. It is yet to be elucidated whether the PFMAP kinase forms in $P$. falciparum are involved in control of growth and differentiation of the parasites or participate in different signal pathways and perform other cell functions (Kappes et al, 1999). Recently, another MAPK homologue was identified in gametocytes of $P$. falciparum (Dorin et al., 1999). It displayed functional characteristics of MAPKs such as (1) ability to undergo autophosphorylation, (2) ability to phosphorylate myelin basic protein, a classical MAPK substrate, (3) regulation of kinase activity by a MAPK-specific phosphatase, and
(4) ability to be activated by component(s) present in cell extracts. But the peculiarity of Pfmap-2 is that it does not have the conserved threonine-X-tyrosine activation motif usually found in enzymes of this family (Dorin et al., 1999).

The phylogenetic analysis has shown that PfMAPs do not specifically cluster with typical MAP kinases (Ward et al., 2004). By analysis of the P. falciparum kinome, Pfmap-2 was shown to be in a basal position relative to the MAPK family, which indicates no preferential relations to any of its subfamilies. Pfmap-1, on the contrary, is clearly associated with ERK8 that is not a part of typical threecomponent (MEKK-MEK-ERK) modules (Ward et al., 2004). This can indicate that other protozoan organisms, although use MAPK homologues, also do not have typical MEKK-MEK-ERK modules.

Many aspects of MAPK signaling in microbial organisms have yet remained unclear. In most cases, unknown are the precise mechanisms of regulation of the signal transduction pathways including the MAP kinase cascades; also not revealed is the PTK role in their activation. The examples presented in this review demonstrate differences, rather than similarity, of trigger mechanisms of the MAP kinase cascade activation in the higher and lower eukaryotes. Although the presence in signal protein networks in the series of unicellular eukaryotes of the growth receptor-like proteins, protein tyrosine kinases, Ras proteins, and Src homology 2 (SH2) of domain-containing proteins suggests that in lower eukaryotes, classical mechanisms of MAP kinase activation with participation of tyrosine phosphorylation also can take place, not all studied eukaryotic microorganisms have been revealed to contain the complete MEKK-MEK-MAPK cascades. In spite of this, it is evident that the MAP kinases activated by extracellular stimuli participate in regulation of fundamental cell processes: mating, proliferation, differentiation, and co-ordination of polarized growth, many of them being common to the higher and lower eukaryote cells. It is to be emphasized that in unicellular eukaryotes the signaling events that do not regulate MAPK activation, like probably in the higher eukaryote cells, may mediate aspects of tyrosine kinase signaling, such as ligand-stimulated cell survival, cytoskeletal rearrangements, cell migration, and chemotaxis (Ridley et al., 1992; Ridley and Hall, 1992).

\section{Stress-activated protein kinases in the lower eukaryotes}

The stress-activated protein kinases SAPK (JNK-p46, SAPK-p54, and p38-MAPK) revealed in the higher eukaryotes, related to ERK1/ERK2, are included in the MAP kinase family (Boulton et al., 1991; Derijard et al., 1994; Han et al., 1994; Kyriakis et al., 1994 Minden et al., 1994). Their activity also depends on processes of tyrosine and threonine phosphorylation; however, whereas the mammalian ERK1/2 are strictly activated by growth factors or phorbol esters (Kyriakis, 1994), SAPK show a high resistance to mitogens, but are activated in response to the heat and osmotic stress, ultraviolet irradiation, and action of cytokines (Brenner et al., 1989; Derijard et al., 1994; Han et al., 1994; Kyriakis et al., 1994; Cho et al., 2001). The initial chain of stress-activated SAPK pathway 
is non-receptor tyrosine kinase, while the terminal chain is the protein product of oncogen c-jun (Fig. 3) (Davis, 1994; Derijard et al., 1994; Kyriakis et al., 1994; Hill and Treisman, 1995).

Stress-activated protein kinases (SAPKs) are also found in several unicellular eukaryotes. One of such kinases is in particular the HOG1 kinase in Saccharomyces cerevisiae, which is activated in response to osmotic stress (Brewster et al., 1993). Analysis of HOG1 sequences has revealed that an area near the $\mathrm{NH}_{2}$-terminus contains a conservative sequence of about 300 amino acids, which has a high degree of homology with sequences in the kinase domain of MAP kinases: human ERK1 and S. cerevisiae FUS3. Like other MAP kinases, HOG1 has sites of phosphorylation at threonine 174 and at tyrosine 176 in the kinase domain VIII. HOG1 is phosphorylated at tyrosine in response to an increase of osmotic gradient. The HOG1 is the central kinase of the multi-cascade stress-activated signal pathway. This pathway is called the HOG pathway, as it controls the high osmolarity glycerol response, and is activated by a yet unidentified osmosensor or SH3-containing osmosensor protein Sho1p (Fig. 3) (Maeda et al., 1995; Posas and Saito, 1997; Raitt et al., 2000). The Sho1p coupled with protein STE50 that is a subunit of STE11, the MEKK family member, and together with STE20 PAK-like kinase activates STE11 by a yet unknown manner. The activated STE11 then apparently activates the PBS2 MEK by phosphorylating it. The PBS2 translates signal to HOG1. Stimulation is rapid, and phosphorylation of HOG1 at both serine/threonine and tyrosine can be observed $1 \mathrm{~min}$ after upshock (Maeda et al., 1995). The activated HOG1 is translocated to the nucleus (Reiser et al., 1999), where it is involved in stimulation of expression of about 150 genes (Posas et al., 2000). Several transcription factors including Hot1, Sko1 and Msp2/Msp4 are associated with the HOG pathway (Rep et al., 2000; Pascual-Ahuir et al., 2001).

Whereas nuclear targets of proteins participating in signal transduction via the HOG1 pathway are described sufficiently well, their cytoplasmic substrates in yeasts remain poorly studied. Mechanisms of regulatory action of signal proteins on effectors also need deciphering.

The kinase similar to the mammalian JNK/SAPK was found in Toxoplasma gondii (Roisin et al., 2000); properties of the T. gondii p53-JNK-like kinase are described in detail in the previous Section. Under experimental conditions this kinase together with other TgMAPKs was activated by $\mathrm{Ca}^{2+}$ influx to result in cell membrane depolarization. It is possible that under natural conditions the JNK-like kinase of $T$. gondii can be activated by interaction of tachyzoites with host cell. The precise mechanisms at present is not clear.

In the ciliate Tetrahymena thermophila the stressactivated MAP kinase MRK has been revealed; it is composed of 430 amino acid residues and resembles by its structure the human and yeast MAP kinases. Analysis of the primary structure has shown this kinase to have $40 \%$ of homology with the human ERK1 (Boulton et al., 1990) and $38 \%$, with yeast HOG1 (Brewster et al., 1993) and the human p38 (Han et al., 1994), as well as a significant degree of homology with human stress-activated kinases (JNK1 and SAPK4). Use of phylogenetic analysis has allowed establishing that MRK of Tetrahymena are closer to p38 JNK/SAPK than to ERK. This kinase is activated in vivo after transfer of the cells cultivated at optimal temperature $\left(35^{\circ} \mathrm{C}\right)$ into conditions of physiological stress induced by a low temperature $\left(15^{\circ} \mathrm{C}\right)$ or an increase of the medium osmolarity. However, in MRK, unlike typical MAP kinases, the highly conservative site of phosphorylation at tyrosine in the kinase subdomain VIII is replaced by histidine (Thr226-Gly-His228). The recombinant MRK expressed in Escherichia coli phosphorylates a specific substrate (the MBP) and is autophosphorylated. When Thr 226 in the mutant recombinant protein is replaced by Ala, kinase loses the capability for autophosphorylation, which indicates an important role of this amino acid in providing MRK with function of dual specificity. Analysis of kinase biochemical properties has shown the mRNA transcript to increase significantly with decrease of temperature from $35^{\circ}$ to $15^{\circ} \mathrm{C}$, the decrease rate being $0.8^{\circ} \mathrm{C} / \mathrm{min}$. The highest mRNA expression of the MRK kinase mRNA is observed $1 \mathrm{hr}$ after the decrease of temperature to $15^{\circ} \mathrm{C}$; this expression level exceeding about threefold the level of expression of MRK mRNA in intact cells is observed for the next $2 \mathrm{hr}$. The osmotic shock induced by sorbitol (100-200 mM) or $\mathrm{NaCl}(25-100 \mathrm{mM})$ also produces expression of MRK mRNA in T. thermophila. That the osmotic shock-induced MRK kinase belongs to the MAP kinase family was established by analysis of the immune kinase complex with use of the specific MAP kinase substrate (Nakashima et al., 1999).

The MRK-like kinase with identical biochemical characteristics and with the $90 \%$ structural homology of the primary structure was revealed in Tetrahymena pyriformis (Nakashima et al., 1999).

The structural-functional organization of the majority of signal pathways of unicellular microorganisms, in which stress-activated MAP kinases take part, has remained unclear so far. There are still too few works evaluating role of tyrosine phosphorylation in regulation of the stress-activated signal transduction pathways and in programming of processes aimed at maintenance of life activity of microbial cells under stress conditions (Schuller et al, 1994; Martinez-Pastor et al., 1996; Moskvina et al., 1998).

It is possible that, like in many metazoan cell systems, the up-stream regulation of the stress-activated signal pathway is independent of tyrosine phosphorylation. However, it is apparent that phosphorylation of microbial PTK at tyrosine is necessary to realize the enzyme kinase activity and to provide transduction of the stress signal into genome.

\section{Participation of STAT-protein of Dictyostelium in intracellular signaling}

At the end of the twentieth century, in mammalian cells the JAK/STAT pathways were revealed; they participated in the transcriptional activation of many cytokine- and growth factor-inducible genes. This illustrates how combinatorial interactions at the receptor itself can determine the kind of activated transcription complex and consequently the 
nature of the target DNA sequence (Darnell et al., 1994; Ihle et al., 1994). STAT proteins that prior to receptor activation appear to be cytoplasmic (Schinndler et al., 1992) bind to their cognate receptor during activation (Fu and Zhang, 1993; Lutticken et al., 1994). Phosphorylation at conserved tyrosine in their $\mathrm{COOH}$-terminus allows STAT dimerization; then an unknown mechanism allows them to leave the receptor and to migrate to the nucleus (Hill and Treisman, 1995). The STAT proteins, apart from the regions of $\mathrm{Src}$ homology ( $\mathrm{SH} 2$ and $\mathrm{SH} 3)$, contain the DNA-binding domain. In vertebrates and Drosophila the JAK-STAT pathway regulates cell proliferation, differentiation, adaptation, and hyperactivation and leads to tumor formation (Gatsios et al., 1998; Bode et al., 1999; Carballo et al., 1999).

The existence of the STAT pathways in the slime mold Dictyostelium discoideum (Kawata et al., 1997; Araki et al., 2003) and in the protozoan parasite Entamoeba histolytica (Cruz-Vera et al., 2003) has turned out to be unexpected. By the present time, the best studied are the STAT pathways of $D$. discoideum.

Among cytoplasmic components of these pathways found in the higher eukaryotes, three isoforms of this protein were identified in cells of $D$. discoideum: DdSTATa, Dd-STATb and Dd-STATc, tyrosine kinases, and a number of regulatory proteins (see below) (Araki et al., 1998, 2003). The fungal STAT forms perform two different biological functions: Dd-STATa and DdSTATb are responsible for transduction of signals about cell differentiation (Kawata et al., 1997; Araki et al., 1998), whereas Dd-STATc regulates transduction of stress signals into genome (Araki et al., 2003).

Mechanisms of activation and pathways of signal transduction through STAT pathways in $D$. discoideum are different. Transduction of morphogenetical signals in slime mold cells is provided by the ligand-mediated activation of the serpentine receptor cAR1. The ligand for cAR1 is extracellular cAMP. This interaction results in producing autocrine factor DIF, a chlorinated phenyl alkanone (Berks et al., 1991) and activation of cytoplasmic PTK (Schweiger et al., 1990; Adler et al., 1996; Kim et al., 1999) that phosphorylates Dd-STATa at tyrosine, which leads to its activation: the capability for transport into the cell nucleus and binding with regulatory elements of target genes. The regulatory Dd-STATa action on processes of $D$. discoideum cell differentiation is realized through activation of transcription of genes ecmA and ecmB responsible for prestalk cell differentiation. It has been established that Dd-STATa can binds to both the ecmA activator and ecmB repressor elements in promoters of these genes, as both types of the regulators contain repeats of TTGA sequences, which are recognized by Dd-STATa (Kawata, 1996; Ceccarelli et al., 2000). Besides, Dd-STATa has recently been shown to act as a transcriptional activator of the gene $c u d A$, whose expression is essential for correction of terminal differentiation of $D$. discoideum (Fukuzawa and Williams, 2000).

So far it is not yet clear whether the STATa pathway participates in regulation of $D$. discoideum apoptosis that is induced in spore cells located in the anterior part of the fruiting body or this process is controlled by other signal pathways. At any rate, such possibility can easily be admitted if to take into account that specificity of the STAT-mediated signal is determined in most cases by the type of the cells (Chin et al., 1997; Schindler, 1998).

Comparison of the primary structure and the biochemical analysis showed Dd-STATa to contain all main protein domains of the STAT group (Kawata, 1997), although the presence of the $\mathrm{SH}$-domain in the DdSTATa molecule has turned out to be quite unexpected, as previously it was believed that this domain was unique for cell STAT proteins of multicellular organisms (Darnell, 1997).

The recombinant Dd-STATa is composed of approximately 700 amino acid residues and contains in its molecule $\mathrm{C}$-terminal half the large areas similar by their primary structures with homologous areas of STAT proteins of the higher eukaryotes. For instance, Dd-STATa in the 241-262 sequences contains leucine-enriched repeats essential for phosphorylation of STAT1 (Improta et al., 1994). In the DNA-binding domain located in the $\mathrm{N}$-terminal half of the protein, Dd-STATa has homology with human STAT5b and Drosophila D-STAT (Hou et al., 1996, Yan et al., 1996; Ehret et al., 2001) and contains homologous sequences concentrated around the conservative pair of valine residues that are essential for DNA binding in the STAT3 molecule (Horvath et al., 1995). Interestingly, the less conservative $\mathrm{SH} 3$-domain has been not detected in Dd-STAT, whereas the highly conservative SH2-domain revealed in all STAT proteins of multicellular organisms is present in both Dd-STAT isoforms.

The STATc pathway in $D$. discoideum is of great significance in maintaining viability of organisms under their unfavorable environmental conditions. So far, little is known about how the stress signal is transmitted through this pathway in microorganisms. The initial stages of this pathway and the exact mechanism of the Dd-STATc activation have not yet been established. Probably, this mechanism in $D$. discoideum, like in the majority of metazoa, is based on its abilities associated with JAKlike tyrosine kinase. Phosphorylation of Dd-STATc leads to its activation and subsequent translocation into the nucleus. So far it is absolutely unclear how this process is realized in the $D$. discoideum cells. It was only shown that Dd-STATc produced transcription of two genes: gapA and rtoA (Araki et al., 2003). The gapA gene - encoded protein of the same name represents a RasGAP-like protein necessary for normal $D$. discoideum cytokinesis (Adachi et al., 1997; Lee et al., 1997; Sakurai et al., 2001). GAPA has homology of its primary structure with mammalian IQGAP proteins and, like its homologues from mammalian cells, is effector for Rac and Cdc42 proteins participating in regulation of the actin cytoskeleton (Kuroda et al., 1996; Epp and Chant, 1997; Osman and Cerione, 1998). The RtoA protein encoded by the gene rto $A$ participates in regulation of the cell cycle (Wood et al., 1996). Both proteins play the key role in recovery of cells after a stress action and thereby participate in the cell systemic response to stress. Future studies using microorganisms are to be continued to provide insights into the roles and regulation of these proteins and their signaling pathways. 


\section{Conclusions}

It is now well established that many intracellular processes are regulated by phosphorylation events. A particularly important role in regulation of such fundamental processes as growth, differentiation, and development is played by processes of tyrosine phosphorylation. This mechanism of regulation of signal transduction pathways was discovered in mammalian cells in the late 1980s and was long considered unique and evolutionarily associated with transition of organisms to multicellularity. However, in a number of unicellular eukaryotes (protozoa, yeasts, myxomycetes), tyrosine kinases activated by growth factors capable for autophosphorylation as well as Ras proteins, MAP kinases including the stress-activated ones, STAT proteins, etc. were identified. This argued in favor of the existence of a similar mechanism of signal transduction also in the lower eukaryotes. Thus, taking into account the above-exposed data, less and less doubts remain that the PTK signaling originates from primitive forms of microbial signal transduction, whose basis consists in processes of phosphorylation at tyrosine.

\section{Acknowledgments}

I am very grateful to N.N. Nikolsky for offering the experimental base and for his valuable advices and support. I also greatly appreciate the practical help of E.B. Burova, R.P. Vasilenko, and P.S. Grudinkin in carrying out the experiments.

\section{References}

Abe, M.K., Kuo, W.L., Hershenson, M.B., and Rosner M.R. (1999) Extracellular signal-regulated kinase 7 (ERK7), a novel ERK with a C-terminal domain that regulates its activity, its cellular localization, and cell growth. Mol. Cell. Biol. 19, 1301-1312.

Abe, M.K., Kusuhara, M., Ulevitch. R.J., Berk, B.C., and Lee, J.D. (1996) Big mitogen-activated protein kinase 1 (BMK1) is a redox-sensitive kinase. J. Biol. Chem. 271, 16586-16590.

Adachi, H., Takahashi, Y., Hasebe, T., Shirouzu, M., Yokoyama, S., and Sutoh, K. (1997) Dictyostelium IQGAP-related protein specifically involved in the completion of cytokinesis. J. Cell Biol. 137, 891-998.

Adler, K., Gerisch, G., von Hugo U., Lupas, A., and Schweiger A. (1996) Classification of tyrosine kinases from Dictyostelium discoideum with two distinct complete or incomplete catalytic domains. FEBS Lett. 395, 286-292.

Alspaugh, J.A., Cavallo, L.M., Perfect, J.R., and Heitman, J. (2000) RAS1 regulates filamentation, mating and growth at high temperature of Cryptococcus neoformans. Mol. Microbiol. 36, 352-365.

Ammerer, G. (1994) Sex, stress, and integrity: the importance of MAP kinases in yeast. Curr. Opin. Genet. Dev. 4, 90-95.

Andersen, H.A., Flodgaard, H., Klenov, H., and Leick, V. (1984) Platelet-derived growth factor stimulates chemotaxis and nucleic acid synthesis in the protozoan Tetrahymena. Biochim. Biophys. Acta. 728, 437-440.

Araki, T., Gamper, M., Early, A., Fukuzawa, M., Abe, T., Kawata, T., Kim, E., Firtel, R.A., and Williams, J.G. (1998) Developmentally and spatially regulated activation of a
Dictyostelium STAT protein by a serpentine receptor. EMBO J. 17, 4018-4028.

Araki, T., Tsujioka, M., Abe, T., Fukuzawa, M., Meima, M., Schaap, P., Morio, T., Urushihara, H., Katoh, M., Maeda, M.., Tanaka, Y., Takeuchi, I., and Williams, J.G. (2003) A STAT-regulated, stress-induced signalling pathway in Dictyostelium. J. Cell Sci. 116, 2907-2915.

Arellano, M., Coll, P.M., and Perez P. (1999) RHO GTPases in the control of cell morphology, cell polarity, and actin localization in fission yeast. Microsc. Res. Tech. 47, 51-60.

Aubry, L., Maeda, M., Insall, R., Devreotes, P.N., and Firtel, R.A. (1997) The Dictyostelium mitogen-activated protein kinase ERK2 is regulated by Ras and CAMPdependent protein kinase (PKA) and mediates PKA function. J. Biol. Chem. 272, 3883-3886.

Bakhiet, M., Olsson, T., Mhlanga, J., Buscher, P., Lycke, N., van der Meide, P.H., and Kristensson K. (1996) Human and rodent interferon-gamma as a growth factor for Trypanosoma brucei. Eur. J. Immunol. 26, 1359-1364.

Barcinski, M.A., and Moreira, M.E. (1994) Cellular responses of protozoan parasites to host-derived cytokines. Parasitol. Today 10, 352-355.

Barcinski, M.A., Shehtman, D., Quintao, L.G., Costa, D.A., Soares, L.R., Moreira, M.E., and Charlab, R. (1992) Granulocyte-macrophage colony stimulating factor increases the infectivety of Leishmania amazonensis by protecting promastigotes from heat-induced death. Infect. Immun. 60, 3523-3527.

Berks, M., Traynor, D., Carrin, I., Insall, R.H., and Kay, R.R. (1991) Diffusible signal molecules controlling cell differentiation and patterning in Dictyostelium. Development Suppl. 1, 131-139.

Bishop, J.M. (1983) Cellular oncogenes and retroviruses. Annu. Rev. Biochem. 52, 301-354.

Bode, J.G., Gatsios, P., Ludwig, S., Rapp, U.R., Haussinger, D., Heinrich, P.C., and Graeve, L. (1999) The mitogen-activated protein (MAP) kinase p38 and its upstream activator MAP kinase kinase 6 are involved in the activation of signal transducer and activator of transcription by hyperosmolarity. J. Biol. Chem. 274, 30222-30227.

Boulton, T.G., Nye, S.H., Robbins, D.J., Ir, N.Y., Radziejewska, E., Morgenbesser, S.D., DePinho, R.A., Panayotatos, N., Cobb, M.N., and Yancopoulos, G.D. (1991) ERKs: a family of protein-serine/threonine kinases that are activated and tyrosine phosphorylated in response to insulin and NGF. Cell 65, 663-675.

Brenner, D.A., O'Hara, M., Angel, P., Chojkier, M., and Karin, M. (1989) Prolonged activation of jun and collagenase genes by tumor necrosis factor - alpha. Nature 337, 661-663.

Brewster, J.L., de Valoir, T., Dwyer, N.D., Winter, E., and Gustin, M.C. (1993)An osmosensing signal transduction pathway in yeast. Science 259, 1760-1763.

Broome, M.A., and Hunter T. (1996) Requirement for c$\mathrm{Scr}$ catalytic activity and the $\mathrm{SH} 3$ domain in plateletderived growth factor and epidermal growth factor mitogenic signalling. Membranes. J. Biol. Chem. 271, 16798-16806. 
Carballo, M., Conde, M., Bekay, R., Martin-Nieto, J., Camacho, M.J., Monteseirin, J., Conde, J., Bedoya, F.J., and Sobrino, F. (1999) Oxidative stress triggers STAT3 tyrosine phosphorylation and nuclear translocation in human lymphocytes. J. Biol Chem. 274, 17580-17586.

Ceccarelli, A., Zhukovskay, N., Kawata, T., Bozzaro, S., and Williams, J. (2000) Characterization of a DNA sequence element that directs Dictyostelium stalk cellspecific gene expression. Differentiation 66, 189-196.

Chang, E.C., Barr, M., Wang, Y., Jung, V., Xu, H.P., and Wigler, M.H. (1994) Cooperative interaction of S. pombe proteins required for mating and morphogenesis. Cell $79,131-141$

Charlab, R., Blaineau, C., Schechtman, D., and Barcinski, M.A. (1990) Granulocyte-macrophage colonystimulating factor is a growth-factor for promastigotes of Leishmania mexicana amazonensis. J. Protozool. 37, 352-357.

Chin, Y.E., Kitagawa, M., Kuida, K., Flawell R.A., and Fu X.A. (1997) Activation of the STAT signalling pathway can cause expression of caspase 1 and apoptosis. Mol. Cell. Biol. 17, 5328-5337.

Cho, S.G., Lee, Y.H., Park, H.S., Ryo, K., Kang, K.W., Park, J., Eom, S.J., Kim, M.J., Chang, T.S., Chou, S.Y., Shim, J., Kim, Y., Dong, M.S., Lee, M.J., Kim, S.G., Ichijo H., and Choi, E.J. (2001) Glutathione Stransferase modules the stress-activated signals by suppressing apoptosis signal-regulating kinase 1. J. Biol. Chem. 276, 12749-12755.

Christopher, G.K., and Sundermann, C.A. (1996) Intracellular insulin binding in Tetrahymena pyriformis. Tissue Cell 28, 427-437.

Chu, D.M., Ferguson, T.J., and Marciano-Cabral F. (2000) Protein kinase activaion and protein phosphorylation in Naegleria fowleri amoebae in response to normal human serum. J. Eukaryot. Microbiol. 47, 40-47.

Chubb, J.R., Wilkins, A., Thomas, G.M., and Insall, R.H. (2000) The Dictyostelium RasS protein is required for macropinocytosis, phagocytosis and the control of cell movement. J. Cell Sci. 113, 709-719.

Cruz-Vera, J., Clara, L., Hernandez-Kelly, R., Mendez, J.A., Perez-Salazar, E., and Ortega, A. (2003) Collageninduced STAT family members activation in Entamoeba histolytica trophozoites. FEMS Microbiol. Lett. 229, 203-209.

Csaba, G., Kovacs, P., and Falus, A. (1995) Human cytokines interleukin (IL)-3 and IL-6 affect the growth and insulin binding of the unicellular organism Tetrahymena. Cytokine 7, 771-774.

Daniel, J., Bush, J., Cardelli, J., Spiegelman, G.B., and Weeks, G. (1994) Isolation of two novel ras genes in Dictyostelium discoideum; evidence for a complex, developmentally regulated ras gene subfamily. Oncogene 9, 501-508.

Darnell, J.E. (1997) STAT's and gene regulation. Science 277, 1630-1635.

Davis, R.J. 1994. MAPKs: new JNK expands the group. Trends. Biochem. Sci. 19, 470-473.

Dearolf, C.R. (1999) JAKs and STATs in invertebrate model organisms. Cell Mol. Life Sci. 55, 1578-1584.

Derijard, B., Hibi, M., Wu, I.H., Barrett T., Su, B., Deng, T., Karin, M., and Davis R.J. (1994) Jnk 1: a protein kinase stimulated by UV light and Ha-Ras that binds and phosphorylates the $c$-Jun activation domain. Cell 76, 1025-1037.

Di Pietro, A., Garcia-MacEira, F.I., Meglecz, E., and Roncero, M.I. (2001) A MAP kinase of the vascular wilt fungus Fusarium oxysporum is essential for root penetration and pathogenesis. Mol. Microbiol. 39, 1140-1152.

Doerig, C.M., Parzy, D., Langsley, G., Horrocks, P., Carter, R., and Doerig, C.D. (1996) A MAP kinase homoloque from the human malaria parasite, related eukaryotic mitogen-activated protein kinases. Gene 177, $1-6$.

Dorin, D., Alano, P., Boccaccio, I., Ciceron, L., Doerig, C., Sulpice, R., Parzy, D., and Doerig, C. (1999) An atypical mitogen-activated protein kinase (MAPK) homologue expressed in gametocytes of the human malaria parasite Plasmodium falciparum. Identification of a MAPK signature. J. Biol. Chem. 274, 29912-29920.

Egan, S.F., and Weinberg, R.A. (1993) The pathway to signal achievement. Nature 365, 781-783.

Ehret, G.B., Reichenbach P., Schindler U., Horvath C.M., Fritz S., Nabholz M., and Bucher P. (2001) DNA binding specificity of different STAT proteins. Comparison of in vitro specificity with natural target sites. J. Biol. Chem. 276, 6675-6688.

Elion, E.A., Satterberg B., and Kranz, J.E. (1993) FUS3 phosphorylates multiple components of the mating signal transduction cascade: evidence for STE12 and FAR1. Mol. Biol. Cell. 4, 495-510.

Elion, E.A. (2000) Pheromone response, mating and cell biology. Curr. Opin. Microbiol. 3, 573-581.

Epp, J.A., and Chant, J. (1997) An IQGAP-related protein controls actin-ring formation and cytokinesis in yeast. Curr. Biol. 7, 921-929.

Errede, B, and Levin, D.A. (1993) A conserved kinase cascade for MAP kinase activation in yeast. Curr. Opin. Cell Biol. 5, 254-260.

Errede, B., Gartner, A., Zhou, Z., Nasmyth, K., and Ammerer, G. (1993) MAP kinase-related FUS3 from Saccharomyces cerevisiae is activated by STE7 in vitro. Nature 362, 261-264.

Errede, B., Cade, R.M., Yashar, B.M., Kamada, Y., Levin, D.E., Irie, K., and Matsumoto, K. (1995) Dynamics and organization of MAP kinase signal pathways. Mol. Reprod. Dev. 42, 477-485.

Esch, R.K., and Firtel, R.A. (1991) cAMP and cell sorting control the spatial expression of a developmentally essential cell-type-specific ras gene in Dictyostelium. Genes Dev. 5, 9-21.

Fawell, S.E., and Lenard, J. (1988) A specific insulin receptor and tyrosine kinase activity in the membranes of Neurospora crassa. Biochem. Biophys. Res. Commun. 155, 59-65.

Feig, L.A., Urano, T., and Cantor, S. (1996) Evidence for a Ras/Ral signaling cascade. TIBS. 21, 438-441.

Firtel, R.A., and Chung, C.Y. (2000) The molecular genetics of chemotaxis: sensing and responding to chemoattractant gradients. Bioessays 22, 603-615.

Fisher, P.R. (1997) Genetics of phototaxis in a model eukaryote, Dictyostelium discoideum. Bioessays 19, 397-407. 
Flores-Robles, D., Rosales, C., Rosales-Encina, J.L., and Talamas-Rohana, P. (2003) Entamoeba histolytica: a beta 1 integrin-like fibronectin receptor assembles a signaling complex similar to those of mammalian cells. Exp. Parasitol. 103, 8-15.

Fronk, J. (1999) Expression of ras-family genes in the cell cycle and during differentiation of the lower eukaryote Physarum polycephalum. Acta Biochim. Pol. 46, 197202.

Fu, X.Y., and Zhang, J.J. (1993) Transcription factor p91 interacts with the epidermal growth factor receptor and mediates activation of the c-fos gene promoter. Cell 74 , 1135-1145.

Fukuzawa, M., and Williams, J.G. (2000) Analysis of the promoter of the cudA gene reveals novel machanisms of Dictyostelium cell type differentiation. Development 127, 2705-2713.

Gartner, A., Nasmyth, K., and Ammerer, G. (1992) Signal transduction in Saccharomyces cerevisiae requires tyrosine and threonine phosphorylation of FUS3 and KSS1. Genes Dev. 6, 1280-1292.

Gaskins, C., Maeda, M., and Firtel, R.A. (1994) Identificationand functionalanalysis of a developmentally regulated extracellular signal-regulated kinase gene in Dictyostelium discoideum. Mol. Cell Biol. 14, 69967012.

Gaskins, C., Clark, A.M., Aubry, L., Segall, J.E., and Firtel, R.A. (1996) The Dictyostelium MAP kinase ERK2 regulates multiple, independent developmental pathways. Genes Dev. 10, 118-128.

Gatsios, P., Terstegen, L., Schliess, F., Haussinger, D., Kerr, I.M., Heinrich P.C., and Graeve, L. (1998) Activation of the Janus kinase/signal transducer and activator of transcription pathway by osmotic shock. J. Biol. Chem. 27, 22962-22968.

Ghansah, T.J., Ager, E.C., Freeman-Junior, P., Villalta, F., and Lima, M.F. (2002) Epidermal growth factor binds to a receptor on Trypanosoma cruzi amastigotes inducing signal transduction events and cell proliferation. J. Eukaryot. Microbiol. 49, 383-390.

Gimeno, C.J., Ljungdahl, P.O., Styles, C.A., Fink, G.R. (1992) Unipolar cell divisions in the yeast S. cerevisiae lead to filamentous growth: regulation by starvation and RAS. Cell 68, 1077-1090.

Gomes, C.M., Monteiro, H.P., Gidlund, M., and Corbett, C.E. (1998) Insulin-like growth factor-I induces phosphorylation in Leishmania (Leishmania) mexicana promastigotes and amastigotes J. Eukaryot. Microbiol. 45, 352-355.

Gomes, C.M., Goto, H., Magnanelli, A.C., Monteiro, H.P., Soares, R.P., Corbett, C.E., and Gidlund, M. (2001) Characterization of the receptor for insulin-like growth factor on Leishmania promastigotes. Exp. Parasitol. 99, 190-197.

Graeser, R., Kury, P., Franklin, R.M., and Kappes, B. (1997) Characterization of a mitogen-activated protein (MAP) kinase from Plasmodium falciparum. Mol. Microbiol. 23, 151-159.

Gugssa, A., Balan, K.V., Macias, C., Ashhraf, M., Lee, C.M., Hollism V.W., Wyche J., and Anderson W.A. (2000) Fibronectin/fibroblast growth factor cell matrix signaling pathways and reciprocal membrane interaction may be the regulators of cell growth and apoptosis in Trypanosoma musculi in co-cultures with fibroblasts. Cytol. Pathol. 32, 281-296.

Han, J., Lee, J.D., Bibbs, L., and Ulevitch, R.J. (1994) A MAP kinase targeted by endotoxin and hyperosmolarity in mammalian cells. Science 265, 808-811.

Hanks, S.K., and Hunter, T. (1995) Protein kinases 6: The eukaryotic protein kinase superfamily: kinase (catalytic) domain structure and classification. FASEB J. 9, 576597.

Heinisch, J.J., Lorberg, A., Schmitz, H.P., and Jacoby, J.J. (1999) The protein kinase C-mediated MAP kinase pathway involved in the maintenance of cellular integrity in Saccharomyces cerevisiae. Mol. Microbiol. 32, 671680.

Heitman, J. (2000) Characterization of alcohol-induced filamentous growth in Saccharomyces cerevisiae. Mol. Biol. Cell. 11, 183-199.

Hernandez-Ramirez, V., Anaya-Ruiz, M, Rios, A., and Talamas-Rohana, P. (2000) Entamoeba histolytica: tyrosine kinase activity induced by fibronectin through the $\beta 1$-Integrin-like molecule. Exp. Parasitol. 95, 8595.

Herskowitz, I. (1995) MAP kinase pathways in yeast: for mating and more. Cell 80, 187-197.

Hide, G., Gray, A., Harrison, C.M., and Tait, A. (1989) Identification of an epidermal growth factor receptor homologue in Trypanosomes. Mol. Biochem. Parasitol. 36, 51-60.

Hill, C.S., and Treisman, R. (1995) Trascriptional regulation by extracellular signals: mechanisms and specificity. Cell $80,199-211$.

Ho, J., and Bretscher, A. (2001) Ras regulates the polarity of the yeast actin cytoskeleton through the stress response pathway. Mol. Biol. Cell. 12, 1541-1555.

Horvath, C.M., Wen, Z., and Darnell, J.E. (1995) A STAT protein domain that determines DNA sequence recognition suggests a novel DNA-binding domain. Genes Dev. 9, 984-994.

Hou, X.S., Melnick, M.B., and Perrimon, N. (1996) Marelle acts downstream of the Drosophila HOP/JAK kinase and encodes a protein similar to the mammalian STATs. Cell 84, 411-419.

Hou, X.S., Zheng, Z., and Perrimon, N. (2002) The Jak/ STAT pathway in model organisms: emerging role cell movement. Dev. Cell 3, 765-778.

Hua, S.B., and Wang, C.C. (1994) Differential accumulation of a protein kinase homolog in Trypanosoma brucei. J. Cell Biochem. 54, 20-31.

Hua, S.B., and Wang, C.C. (1997) Interferon-gamma activation of a mitogen-activated protein kinase, KFR1, in the bloodstream form of Trypanosoma brucei. J. Biol. Chem. 272, 10797-10803.

Hughes, D.A., Ashworth, A., and Marshall, C.J. (1993) Complementation of byr1 in fission yeast by mammalian MAP kinase kinase requires coexpression of Raf kinase. Nature 364, 349-352.

Hughes, D.A. (1995) Control of signal transduction and morphogenesis by Ras. Semin. Cell Biol. 6, 89-94.

Hunter, T. (1995) Protein kinases and phosphatases: the yin and yang of protein phosphorylation and signaling. Cell 80, 225-236. 
Hunter, T., and Cooper, J.A. 1985. Protein-tyrosine kinases. Annu. Rev. Biochem. 54, 897-930.

Ihle, J.N. (1994) The Janus kinase family and signaling through members of the cytokine receptor superfamily. Proc. Soc. Exp. Biol. Med. 206, 268-272.

Improta, T., Schindler, C., Horvath, C.M., Kerr, I.M., Stark, G.R., and Darnell, J.E. (1994) Transcription factor ISGF3 formation requires phosphorylated Stat91 protein, but Stat113 protein is phosphorylated independendently of Stat91 protein. Proc. Natl. Acad. Sci. USA. 91, 47764780.

Insall, R.H., Borleis, J., and Devreotes, P.N. (1996) The aimless RasGEF is required for processing of chemotactic signals through G-protein-coupled receptors in Dictyostelium. Curr. Biol. 6, 719-729.

Irie, K., Takase, M., Lee, K.S., Levin, D.E., Araki, H., Matsumoto, K., and Oshima, Y. (1993) MKK1 and MKK2, which encode Saccharomyces cerevisiae mitogen-activated protein kinase-kinase homologs, function in the pathway mediated by protein kinase C. Mol. Cell Biol. 13, 3076-3083.

Jaffer, Z.M., Khosla, M., Spiegelman, G.B., and Weeks, G. (2001) Expression of activated Ras during Dictyostelium development alters cell localization and changes cell fate. Development 128, 907-916.

Jung, U.S., and Levin D.E. (1999) Genome-wide analysis of gene expression regulated by the yeast cell wall integrity signalling pathway. Mol. Microbiol. 34, 10491057.

Kae, H., Lim, C.J., Spiegelman, G.B., Weeks, G. (2004) Chemoattractant-induced Ras activation during Dictyostelium aggregation. EMBO Rep. 5, 602-606.

Kamada, Y., Jung, U.S., Piotrowski, J., and Levin, D.E. (1995) The protein kinase C-activated MAP kinase pathway of Saccharomyces cerevisiae mediates a novel aspect of the heat shock response. Genes Dev. 9, 1559-1571.

Kappes, B., Doerig, C.D., and Graeser R. (1999) An owerview of Plasmodium protein kinases. Parasitol. Today 15, 449-454.

Kataoka, T., Powers, S., McGill, C., Fasano, O., Strathern, J., Broach, J., and Wigler, M. (1984) Genetic analysis of yeast RAS1 and RAS2 genes. Cell 37, 437-445.

Kawata, T., Early, A., and Williams, J.G. (1996) Evidence that a combined activator-repressor protein regulates Dictyostelium stalk cell differentiation. EMBO J. 15, 3085-3092.

Kawata, T., Shevchenko, A., Fukuzawa, M., Jermyn, K.A., Totty, N.F., Zhukovskaya, N.V., Sterling, A.E., Mann, M., Williams, J.G. (1997) SH2 signaling in a lower eukaryote: A STAT protein that regulates stalk cell differentiation in Dictyostelium. Cell 89, 909-916.

Kayne, P.S., and Sternberg, P.W. (1995) Ras pathways in Caenorhabditis elegans. Curr. Opin. Genet. Dev. 5, 38-43.

Ketela, T., Green, R., andBussey, H. (1999) Saccharomyces cerevisiae mid2p is a potential cell wall stress sensor and upstream activator of the PKC1-MPK1 cell integrity pathway. J. Bacteriol. 181, 3330-3340.

Khosla, M., Spiegelman, G.B., and Weeks, G. (1996) Overexpression of an activated ras $G$ gene during growth blocks the initiation of Dictyostelium development. Mol. Cell Biol. 16, 4156-4162.

Khosla, M., Spiegelman, G.B., Insall, R., and Weeks, G. (2000) Functional overlap of the dictyostelium RasG, RasD and RasB proteins. J. Cell Sci. 113, 1427-1434.

Kim, L., Liu, J., and Kimmel, A.R. (1999) The novel tyrosine kinase ZAK1 activates GSK3 to direct cell fate specification. Cell 99, 399-408.

Kole, H.K., and Lenard, J. (1991) Insulin-induced stimulation of protein phosphorylation in Neurospora crassa cells. FASEB J. 5, 2728-2734.

Kosaka, C., Khosla, M., Weeks, G., and Pears, C. (1998) Negative influence of RasG on chemoattractant-induced ERK2 phosphorylation in Dictyostelium. Biochim. Biophys. Acta. 1402, 1-5.

Kozlowski, P., Trzcinska-Danielewicz, J., Toczko, K. (1996) Identification and sequence analysis of a rap gene from the true slime mold Physarum polycephalum. Biochim. Biophys. Acta. 1305, 29-33.

Kranz, J.E., Satterberg, B., and Elion, E.A. (1994) The MAP kinase Fus3 associates with and phosphorylates the upstream signaling component Ste5. Genes Dev. 8, 313-327.

Krause, S.A., and Gray, J.V. (2002) The protein kinase $C$ pathway is required for viability in quiescence in Saccharomyces cerevisiae. Curr. Biol. 12, 588-593.

Kruse, M., Muller I.M., and Muller W.E.G. (1997) Early evolution of metazoan serine/threonine- and tyrosine kinases: identification of selected kinases in marine sponges. Mol. Biol. Evol. 14, 1326-1334.

Kubler, E., Mosch, H.U., Rupp, S., Lisanti, M.P. (1997) Gpa2p, a G-protein alpha-subunit, regulates growth and pseudohyphal development in Saccharomyces cerevisiae via a cAMP-dependent mechanism. J. Biol. Chem. 272, 20321-20323.

Kumagai, A., Hadwiger, J.A., Pupillo, M., and Firtel, R.A. (1991) Molecular genetic analysis of two $G$ alpha protein subunits in Dictyostelium. J. Biol. Chem. 266, 1220-1228.

Kuroda, S., Fukata, M., Kobayashi, K., Nakafuku, M., Nomura, N., Iwamatsu, A., and Kaibuchi, K. (1996) Identification of IQGAP as a putative target for the small GTPases, Cdc42 and Rac1. J. Biol. Chem. 271, 23363-23367.

Kurvari, V., Zhang, Y., Luo Y., and Snell, W.J. (1996) Molecular cloning of a protein kinase whose phosphorylation is regulated by genetic adhesion during Chlamydomonas fertilization. Proc. Natl. Acad. Sci USA. 93, 39-43.

Kuwayama, H., Oyama, M., Kubohara, Y., and Maeda, M. (2000) A novel role of differentiation-inducing factor-1 in Dictyostelium development, assessed by the restoration of a developmental defect in a mutant lacking mitogenactivated protein kinase ERK2. Dev. Growth Differ. 42, 531-538.

Kyriakis, J.M., Banerjee, P., Nikolakaki, E., Dai, T., Rubie, E.A., Ahmad, M.F., Avruch, J., and Woodgett, J.R. (1994) The stress-activated protein kinase subfamily of c-Jun kinases. Nature 369, 156-160.

Lee, K.S., Irie, K., Gotoh, Y., Watanabe, Y., Araki, H., Nishida, E., Matsumoto, K., and Levin, D.E. (1993) A yeast mitogen-activated protein kinase homolog 
(Mpk1p) mediates signalling by protein kinase C. Mol. Cell Biol. 13, 3067-3075.

Lee, K.S., and Levin, D.E. (1992) Dominant mutations in a gene encoding a putative protein kinase (BCK1) bypass the requirement for a Saccharomyces cerevisiae protein kinase C homolog. Mol. Cell Biol. 12, 172-182.

Lee, S., Escalante, R., and Firtel, R.A. (1997) A Ras GAP is essential for cytokinesis and spatial patterning in Dictyostelium. Development 124, 983-996.

Lee, S., Parent, C.A., Insall, R., and Firtel, R.A. (1999) A novel Ras-interacting protein required for chemotaxis and cyclic adenosine monophosphate signal relay in Dictyostelium. Mol. Biol. Cell. 10, 2829-2845.

Leick, V., Iversen, C., Kemp, K., and Christensen, S.T. (1997) Protein kinase inhibitors abolish adaptative cell behavior Tetrahymena. Acta Protozool. 36, 249-260.

Levin, D.E., and Bartlett-Heubusch, E. (1992) Mutants in the $S$. cerevisiae PKC1 gene display a cell cycle-specific osmotic stability defects. J. Cell Biol. 116, 1221-1229.

Li, Y.C., Chen, C.R., and Chang, E.C. (2000) Fission yeast Ras1 effector Scd1 interacts with the spindle and affects its proper formation. Genetics 156, 995-1004.

Lim, C.J., Spiegelman, G.B., and Weeks, G. (2001) RasC is required for optimal activation of adenylyl cyclase and Akt/PKB during aggregation. EMBO J. 20, 4490-4499.

Lim, C.J., Spiegelman, G.B., and Weeks, G. (2002) Cytoskeletal regulation by Dictyostelium Ras subfamily proteins. J. Muscle Res. Cell Motil. 23, 729-736.

Lin, D.T., Goldman, N.D., and Syin, C. (1996) Stagespecific expression of a Plasmodium falciparum protein related eukaryotic mitogen-activated protein kinases. Mol. Biochem. Parasitol. 78, 67-77.

Loomis, W.F. (1998) Role of PKA in the timing of developmental events in Dictyostelium cells. Microbiol. Mol. Biol. Rev. 62, 684-694.

Lorenz, M.C., Cutler, N.S., and Lorenz, M.C., Cutler, N.S., Heitman, J. (2000) Characterization of alcohol-induced filamentous growth in Saccharomyces cerevisiae. Mol. Biol. Cell. 11, 183-199.

Louis, S.A., Spiegelman, G.B., Weeks, G. (1997) Expression of an activated ras $D$ gene changes cell fate decisions during Dictyostelium development. Mol. Biol. Cell. 8, 303-312.

Lujan, H.D., Mowatt, M.R., Helman, L.J., and Nash, Th.E. (1994) Insulin-like G growth factors stimulate growth and L-cysteine uptake by the intestinal parasite Giardia lamblia. J. Biol. Chem. 269, 13069-13072.

Lutticken, C., Wegenka, U.M., Yuan, J., Buschmann. J., Schindler. C., Ziemiecki. A., Harpur, A.G., Wilks, A.F., Yasukawa, K., and Taga, T. (1994) Association of transcription factor APRF and protein kinase Jak1 with the interleukin-6 signal transducer gp130. Science 263 , 89-92.

Maeda T., Takekawa M., and Saito, H. (1995) Activation of yeast PBS2 MAPKK by MAPKKKs or by binding of an SH3-containing osmosensor. Science 269, 554-558.

Maeda M., and Firtel R.A. (1997) Activation of the mitogenactivated protein kinase ERK2 by the chemoattractant folic acid in Dictyostelium. J. Biol. Chem. 272, 2369023695.

Maeda, M., Aubry, L., Insall, R., Gaskins, C., Devreotes, P.N., and Firtel R.A. (1996) Seven helix chemoattractant receptors transiently stimulate mitogen-activated protein kinase in Dictyostelium. J. Biol. Chem. 271, 3351-3354.

Marshall, C.J. (1995) Specificity of receptor tyrosine kinase signaling: transient versus sustained extracellular signal-regulated kinase activation. Cell 80, 179-185.

Martinez-Pastor, M.T., Marchler, G., Schuller, C., Marchler-Bauer, A., Ruis, H., and Estruch, F. (1996) The Saccharomyces cerevisiae zinc finger proteins Msn2p and Msn4p are required for transcriptional induction through the stress response element (STRE) EMBO J. 15, 2227-2235.

Meili, R., Ellsworth, C., Lee, S., Reddy, T.B., Ma, H., and Firtel, R.A. (1999) Chemoattractant-mediated transient activation and membrane localization of Akt/ $\mathrm{PKB}$ is required for efficient chemotaxis to cAMP in Dictyostelium. EMBO J. 18, 2092-2105.

Minden, A., Lin, A., McMahon, M., Lange-Carter, C., Derijard, B., Davis, R.J., Johnson, G.L., and Karin M. (1994) Differential activation of ERK and JNK mitogenactivated protein kinases by Raf-1 and MEKK. Science 266, 1719-1723.

Mishra, N.C., Sharma, M., and Sharma, A. (1999) Inhibitory effect of piceatannol, a protein tyrosine kinase inhibited asexual maturation of Plasmodium falciparum. Indian J. Exp. Biol. 37, 418-420.

Moodie, S.A., Willumsen, B.M., Weber, M.J., and Wolfman, A. (1993) Complexes of RasGTF with Raf-1 and mitogen-activated protein kinase kinase. Science 260, 1658-1661.

Moskvina, E., Schuller, C., Maurer, C.T., Mager, W.H., and Ruis, H. (1998) A search in the genome of Saccharomyces cerevisiae for genes regulated via stress response elements. Yeast 14, 1041-1050.

Mosch, H.U., Roberts, R.L., and Fink, G.R. (1996) Ras2 signals via the Cdc42/Ste20/mitogen-activated protein kinase module to induce filamentous growth in Saccharomyces cerevisiae. Proc. Natl. Acad. Sci. USA. 93, 5352-5356.

Mosch, H.U., and Fink, G.R. (1997) Dissection of filamentous growth by transposon mutagenesis in Saccharomyces cerevisiae. Genetics 145, 671-684.

Mosch, H.U., Kubler, E., Krappmann, S., Fink, G.R., and Braus, G.H. (1999) Crosstalk between the Ras2pcontrolled mitogen-activated protein kinase and cAMP pathways during invasive growth of Saccharomyces cerevisiae. Mol. Biol. Cell. 10, 1325-1335.

Mustafa, E., Bakhiet, M., Jaster, R., Bittorf, Th., and Olsson, T. (1997) Tyrosine kinases are required for interferon- $\gamma$ - stimulated proliferation of Trypanosoma brucei brucei. J. Infect. Dis. 175, 669-673.

Mustelin, T., Abraham, R.T., Rudd, C.E., Alonso, A., and Merlo, J.J. (2002) Protein tyrosine phosphorylation in $T$ cell signaling. Front. Biosci. 7, d918-d969.

Nakashima, S., Wang, S., Hisamoto, N., Sakai, H., Andoh, M., Matsumoto, K., and Nozawa, Y. (1999) Molecular cloning and expression of a stress responsive mitogen-activated protein kinase-related kinase from Tetrahymena cells. J. Biol. Chem. 274, 9976-9983.

Neiman, A.M. (1993) Conservation and reiteration of a kinase cascade. Trends Genet. 9, 390-394. 
Neiman, A.M., and Herskowitz, I. (1994) Reconstitution of a yeast protein kinase cascade in vitro: activation of the yeast MEK homologue STE7 by STE11. Proc. Natl. Acad. Sci. USA. 91, 3398-3402.

Ng, H.C., Singh, M., and Jeyaseelan, K. (1995) Identification of two protein serine/threonine kinase genes and molecular cloning of a SNF1 type protein kinase gene from Toxoplasma gondii. Biochem. Mol. Biol. Int. 35, 155-165.

Nikawa, J., Cameron, S., Toda, T., Ferguson, K.M., and Wigler, M. (1987) Rigorous feedback control of cAMP levels in Saccharomyces cerevisiae. Genes Dev. 1, 931-937.

Ng, H.C., Singh, M., and Jeyaseelan, K. (1997) Nucleotide sequence of ToxPK1 gene from Toxoplasma gondii. DNA Seq. 7, 179-191.

Tanaka, K., Nakafuku, M., Satoh, T., Marshall, M.S., Gibbs, J.B., Matsumoto, K,, Kaziro, Y., and Toh-e, A. (1990) S. cerevisiae genes IRA1 and IRA2 encode proteins that may be functionally equivalent to mammalian ras GTPase activating protein. Cell 60, 803-807.

Thevelein, J.M., and de Winde, J.H. (1999) Novel sensing mechanisms and targets for the CAMP-protein kinase $\mathrm{A}$ pathway in the yeast Saccharomyces cerevisiae. Mol. Microbiol. 33, 904-918.

Nonaka, H., Tanaka, K., Hirano, H., Fujiwara, T., Kohno, H., Umikawa, M., Mino, A., and Takai, Y. (1995) A downstream target of $\mathrm{RHO} 1$ small GTP-binding protein is PKC1, a homolog of protein kinase C, which leads to activation of the MAP kinase cascade in Saccharomyces cerevisiae. EMBO J. 14, 5931-5938.

Olsson, T., Bakheit, M., and Kristensson, K. (1992) Interactions between Trypanosoma brucei and $\mathrm{CD}^{+} \mathrm{T}$ cells. Parasitol. Today 79, 202-205.

Osman, M.A., Konopka, J.B., and Cerione, R.A. (2002) lqg1p links spatial and secretion landmarks to polarity and cytokinesis. J. Cell Biol. 159, 601-611.

Pan, X., and Heitman, J. (1999) Cyclic AMP-dependent protein kinase regulates pseudohyphal differentiation in Saccharomyces cerevisiae. Mol. Cell Biol. 19, 48744887.

Papadaki, P., Pizon, V., Onken, B., and Chang, E.C. (2002) Two ras pathways in fission yeast are differentially regulated by two ras guanine nucleotide exchange factors. Mol. Cell Biol. 22, 4598-4606.

Paravicini, G., Cooper, M., Friedli, L., Smith, D.J., Carpentier, J.L., Klig, L.S., and Payton, M.A. (1992) The osmotic integrity of the yeast cell requires a functional PKC1 gene product. Mol. Cell Biol. 12, 4896-4905.

Park, H.O., Kang, P.J., and Rachfal, A.W. (2002) Localization of the Rsr1/Bud1 GTPase involved in selection of a proper growth site in yeast. J. Biol. Chem. 277, 26721-26724.

Parsons, M., Valentine, M., and Carter, V. (1993) Protein kinases in divergent eukaryotes: Identification of protein kinase activities regulated during Trypanosoma development. Proc. Natl. Acad. Sci. USA. 90, 26562660.

Parsons, M., Valentine, M., Deans, J., Schieven, G.L., Ledbetter, J.A. (1990) Distinct patterns of tyrosine phosphorylation during the life cycle of Trypanosoma brucei. Mol. Biochem. Parasitol. 45, 241-248.
Pascual-Ahuir, A., Serrano, R., and Proft, M. (2001) Sko1p-repressor and Gcn4p-activator antagonistically modulate stress-regulated transcription in Saccharomyces cerevisiae. Mol. Cell. Biol. 21, 16-25.

Peter, M., and Herskowitz I. (1994) Direct inhibition of the yeast cyclin-dependent kinase Cdc28-CIn by Far1. Science 265, 1228-1231.

Philip, B., and Levin, D.E. (2001) Wsc1 and Mid2 are cell surface sensors for cell wall integrity signaling that act through Rom2, a guanine nucleotide exchange factor for Rho1. Mol. Cell Biol. 21, 271-280.

Posas, F., and Saito, H. (1997) Osmotic activation of the HOG MAPK pathway via STE11p MAPKKK: Scaffold role of Pbs2p MAPKK. Science 276, 1702-1705.

Posas, F., Chambers, J.R., Heyman J.A., Hoeffler, J.P., de Nadal, E., and Arino, J. (2000) The transcriptional response of yeast to saline stress. J. Biol. Chem. 275, 17249-17255.

Powers, S., Kataoka, T., Fasano, O., Goldfarb, M., Strathern, J., Broach, J., and Wigler, M. (1984) Genes in $S$. cerevisiae encoding proteins with domains homologous to the mammalian ras proteins. Cell 36 , 607-612.

Qadota, H., Python, C.P., Inoue, S.B., Arisawa, M., Anraku, Y., Zheng, Y., Watanabe, T., Levin, D.E., and Ohya Y. (1996) Identification of yeast Rho1p GTPase as a regulatory subunit of 1,3-beta-glucan synthase. Science 272, 279-281.

Raitt, D.C., Posas, F., and Saito, H. (2000) Yeast Sdc42 GTPase and Ste20 PAK-like kinase regulate Sho1dependent activation of the Hog1 MAPK pathway. EMBO J. 19, 4623-4631.

Reinoso-Martin, C., Schuller, C., Schuetzer-Muehlbauer, M., and Kuchler, K. (2003) The yeast protein kinase C cell integrity pathway mediates tolerance to the antifungal drug caspofungin through activation of SIt2p mitogen-activated protein kinase signaling. Eukaryot. Cell. 2, 1200-1210.

Reiser, V., Ruis, H., and Ammerer, G. (1999) Kinase activity-dependent nuclear export opposes stressinduced nuclear accumulation and retention of Hog1 mitogen-activated protein kinase in the budding yeast Saccharomyces cerevisiae. Mol. Biol. Cell. 10, 11471161.

Rep, M., Krantz, M., Trevelein, J.M., and Hohmann, S. (2000) The transcriptional response of Saccharomyces cerevisiae to osmotic shock. Hot1p and Msn2p/Msp4p are required for the induction of subsets of high osmolarity glycerol pathway-dependent genes. J. Biol. Chem. 275, 8290-8300.

Reuther, G.W., and Der, C.J. (2000) The Ras branch of small GTPases: Ras family members don't fall far from the tree. Curr. Opin. Cell Biol. 12, 157-165.

Reymond, C.D., Gomer, R.H., Mehdy, M.C., and Firtel, R.A. (1984) Developmental regulation of a Dictyostelium gene encoding a protein homologous to mammalian ras protein. Cell 39, 141-148.

Ridley, A.J., and Hall, A. (1992) The small GTP-binding protein rho regulates the assembly of focal adhesions and actin stress fibers in response to growth factors. Cell 70, 389-399. 
Ridley, A.J., Paterson, H.F., Johnston, C.L., Diekmann, D., and Hall, A. (1992) The small GTP-binding protein rac regulates growth factor-induced membrane ruffling. Cell 70, 401-410.

Robbins, D.J., Zhen, E., Owaki, H., Vanderbilt, C.A., Ebert, D., Geppert, T.D., and Cobb, M.H. (1993) Regulation and properties of extracellular signal-regulated protein kinase 1 and 2 in vitro. J. Biol. Chem. 268, 5097-5106.

Robbins, S.M., Williams, J.G., Jermyn, K.A., Spiegelman, G.B., and Weeks, G. (1989) Growing and developing Dictyostelium cells express different ras genes. Proc. Natl. Acad. Sci USA. 86, 938-942.

Robbins, S.M., Suttorp, V.V., Weeks, G., and Spiegelman, G.B. (1990) A ras-related gene from the lower eukaryote Dictyostelium that is highly conserved relative to the human rap genes. Nucleic Acids Res. 18, 5265-5269.

Roberts, R.L., and Fink, G.R. (1994) Elements of a single MAP kinase cascade in Saccharomyces cerevisiae mediate two developmental programs in the same cell type: mating and invasive growth. Genes Dev. 8, 29742985.

Roberts, R.L., Mosch, H.U., and Fink, G.R. (1997) 14-3-3 proteins are essential for RAS/MAPK cascade signaling during pseudohyphal development in $S$. cerevisiae. Cell 89, 1055-1065.

Robinson, L.C., Gibbs, J.B., Marshall, M.S., Sigal, I.S., and Tatchell, K. (1987) CDC25: a component of the RAS-adenylate cyclase pathway in Saccharomyces cerevisiae. Science. 235, 1218-1221.

Roisin, M.P., Robert-Gangneux, F., Creuzet, C., and Dupouy-Camet, J. (2000) Biochemical characterization of mitogen-activated protein (MAP) kinase activity in Toxoplasma gondii. Parasitol. Res. 86, 588-598.

Rupp, S., Summers, E., Lo, H.J., Madhani, H., and Fink, G. (1999) MAP kinase and cAMP filamentation signaling pathways converge on the unusually large promoter of the yeast FLO11 gene. EMBO J. 18, 1257-1269.

Sakurai, M., Adachi, H., and Sutoh, K. (2001) Mutational analyzes of Dictyostelium IQGAP-related protein GAPA: possible interaction with small GTPases in cytokinesis. Biosci. Biotechnol. Biochem. 65, 1912-1916.

Salotra, P., Chauhan, D., Ralhan, R., and Bhatnagar, R. (1995) Tumor necrosis factor-alpha induces preferential expression of stress proteins in virulent promastigotes of Leishmania donovani. Immunol. Lett. 44, 1-5.

Salotra, P., Ralhan, R., and Sreenivas, G. (2000) Stress induced modulation of protein phophorylation in promastigotes of Leishmania donovani. Int. J. Biochem. Cell Biol. 32, 309- 316.

Schaloske, R., and Malchow, D. (1997) Mechanism of cAMP-induced $\mathrm{Ca} 2+$ influx in Dictyostelium: role of phospholipase A2. Biochem. J. 327, 233-238.

Schartl, M., and Barnekow, A. (1982) The expression in eukaryotes of a tyrosine kinase which is reactive with pp60v-src antibodies. Differentiation 23, 109-114.

Schartl, M., Holstein, T., Robertson, S.M., and Barnekow, A. (1989) Preferential expression of a pp60c-src related protein tyrosine kinase activity in nerve cells of the early metazoan Hydra (Coelenterates) Oncogene 4, 11851191.

Schindler, C. (1998) Cytokines and JAK-STAT signalling. Exp. Cell Res. 253, 7-14.
Schuller, C., Brewster, J.L., Alexander, M.R., Gustin, M.C., and Ruis H. (1994) The HOG pathway controls osmotic regulation of transcription via the stress response element (STRE) of the Saccharomyces cerevisiae CTT1 gene. EMBO J. 13, 4382-4389.

Schweiger, A., Mihalache, O., Muhr, A., and Adrian, I. (1990) Phoshphotyrosine-containing proteins in Dictyostelium discoideum. FEBS Lett. 268, 199-202.

Secko, D.M., Insall, R.H., Spiegelman, G.B., and Weeks, G. (2004) The identification of Dictyostelium phosphoproteins altered in response to the activation of RasG. Proteomics 4, 2629-2639.

Segall, J.E., Kuspa, A., Shaulsky, G., Ecke, M., Maeda, M., Gaskins, C., Firtel, R.A., Loomis, W.F. (1995) A MAP kinase necessary for receptor-mediated activation of adenylyl cyclase in Dictyostelium. J. Cell Biol. 128, 405-413.

Seger, R., and Krebs, E.G. (1995) The MAPK signaling cascade. FASEB J. 9, 726-735.

Selivanova, G.V., Shemarova, I.V., and Vlasova, T.D. (2002) Epidermal growth factor stimulates proliferation and DNA synthesis in ciliate cells. Ontogenez 33, 457460.

Sengupta, K., Hernandez-Ramirez, V.I., Rios, A., Mondragon, R., and Talamas-Rohana, P. (2001) Entamoeba histolytica: monoclonal antibody against the beta1 integrin-like molecule (140 kDa) inhibits cell adhesion to extracellular matrix components. Exp. Parasitol. 98, 83-89.

Sengupta K, Hernandez-Ramirez V.I., and TalamasRohana P. (2000) Monoclonal antibody specific to the beta1 integrin-like molecule (140 kDa) immunoprecipitates a protein complex of Entamoeba histolytica. Arch. Med. Res. (4 Suppl), S147-S148.

Sharma, A. (2000) Protein tyrosine kinase activity in human malaria parasite Plasmodium falciparum. Indian J. Exp. Biol. 38, 1222-1226.

Sharma, A., and Mishra, N.C. (1999) Inhibition of a protein tyrosine kinase activity in Plasmodium falciparum by chloroquine. Indian J. Biochem. Biophys. 36, 299-304.

Sharma, P., Pillai C.R., and Sharma D.J. (2000) In vitro schizontocidal activity of standard antimalarial drugs on chloroquine-sensitive and chloroquine-resistant isolates of Plasmodium falciparum. Indian J. Exp. Biol. 38, 1129-1133.

Shaulsky, G., Fuller, D., and Loomis, W.F. (1998) A cAMP-phosphodiesterase controls PKA-dependent differentiation. Development 125, 691-699.

Shemarova, I.V., Selivanova, G.V., and Vlasova, T.D. (2002) The influence of epidermal growth factor and insulin on proliferation and DNA synthesis in ciliates Tetrahymena pyriformis. Tsitologiia 44, 1097-1103.

Shemarova, I.V., Selivanova, G.V., and Vlasova, T.D. (2004) Cytophotometric research of epidermal growth factor influence on DNA and protein synthesis in ciliata Tetrahymena pyriformis. Tsitologiia 46, 993-995.

Shen, P.S., Lohia, A., and Samuelson, J. (1994) Molecular cloning of ras and rap genes from Entamoeba histolytica. Mol. Biochem. Parasitol. 64, 111-120.

Shields, J.M., Pruitt, K., McFall, A., Shaub, A., and Der, C.J. (2000) Understanding Ras: 'it ain't over 'til it's over'. Trends Cell Biol. 10, 147-154. 
Shima, F., Okada, T., Kido, M., Sen, H., Tanaka, Y., Tamada, M., Hu, C.D., Yamawaki-Kataoka, Y., Kariya, K., and Kataoka, T. (2000) Association of yeast adenylyl cyclase with cyclase-associated protein CAP forms a second Ras-binding site which mediates its Rasdependent activation. Mol. Cell Biol. 20, 26-33.

Shiu, S.H., and Li, W.H. (2004) Origins, lineage-specific expansions, and multiple losses of tyrosine kinases in eukaryotes. Mol. Biol. Evol. 21, 828-840.

Shuai, K., Ziemiecki, A., Wilks, A.F., Harpur, A.G., Sadowski, H.B., Gilman, M.Z., and Darnell, J.E. (1993) Polypeptide signalling to the nucleus through tyrosine phosphorylation of Jak and Stat proteins. Nature 366, 580-583.

Sowa, M.P., Coulter, L.J., Tait, A., and Hide, G. (1999) A novel gene encoding a ras-like GTP-binding protein from Trypanosoma brucei: an evolutionary ancestor of the ras and rap genes of higher eukaryotes? Gene 230, 155-161.

Stanhill, A., Schick, N., and Engelberg, D. (1999) The yeast ras/cyclic AMP pathway induces invasive growth by suppressing the cellular stress response. Mol. Cell Biol. 19, 7529-7538.

Talamas-Rohana, P., Hernandez-Ramirez, V.I., PerezGarcia, J.N., and Ventura-Juarez, J. (1998) Entamoeba histolytica contains a beta 1 integrin-like molecule similar to fibronectin receptors from eukaryotic cells. J. Eukaryot. Microbiol. 45, 356-360.

Tanaka, K., Nakafuku, M., Satoh, T., Marshall, M.S., Gibbs, J.B., Matsumoto, K, Kaziro, Y., and Toh-e, A. (1990) $S$. cerevisiae genes IRA1 and IRA2 encode proteins that may be functionally equivalent to mammalian ras GTPase activating protein. Cell 60, 803-807.

Tatchell, K., Chaleff, D.T., DeFeo-Jones, D., and Scolnick, E.M. (1984) Requirement of either of a pair of rasrelated genes of Saccharomyces cerevisiae for spore viability. Nature 309, 523-527.

Thelu, J., Bracchi, V., Burnod, J., and Ambroise-Thomas P. (1994) Evidence for expression of a Ras-like and a stage specific GTP binding homologous protein by Plasmodium falciparum. Cell Signal. 6, 777- 782.

Toda, T., Uno, I., Ishikawa, T., Powers, S., Kataoka, T., Broek, D., Cameron, S., Broach, J., Matsumoto, K., and Wigler, M. (1985) In yeast, RAS proteins are controlling elements of adenylate cyclase. Cell 40, 27-36.

Torres, J., Di Como, C.J., Herrero, E., and De La TorreRuiz, M.A. (2002) Regulation of the cell integrity pathway by rapamycin-sensitive TOR function in budding yeast. J. Biol. Chem. 277, 43495-43504.

Tuxworth, R.I., Cheetham, J.L., Machesky, L.M., Spiegelmann, G.B., Weeks, G., and Insall, R.H. (1997) Dictyostelium RasG is required for normal motility and cytokinesis, but not growth. J. Cell Biol. 138, 605-614.

Ushiro H., and Cohen S. (1980) Identification of phosphotyrosine as a product of epidermal growth factor-activated protein kinase in A-431 cell membranes J. Biol. Chem. 255, 8363-8365.

Van Es, S., Kooistra, R.A., Schaap, P. (1997) Two ras genes in Dictyostelium minutum show high sequence homology, but different developmental regulation from Dictyostelium discoideum rasD and ras $G$ genes. Gene 187, 93-97.
Wang, Y., Liu, J., and Segall, J.E. (1998) MAP kinase function in amoeboid chemotaxis. J. Cell Sci. 111, 373383.

Ward, P., Equinet, L., Packer, J., and Doerig, C. (2004) Protein kinases of the human malaria parasite Plasmodium falciparum: the kinome of a divergent eukaryote. BMC Genomics 5, 79-98.

Wassarman, D.A., Therrien, M., and Rubin, G.M. (1995) The Ras signaling pathway in Drosophila. Curr. Opin. Genet. Dev. 5, 44-50.

Weeks, G., and Spiegelman, G.B. (2003) Roles played by Ras subfamily proteins in the cell and developmental biology of microorganisms. Cell Signal. 15, 901-909.

Welburn, S.C., Dale, C., Ellis, D., Beecroft, R., and Pearson, T.W. (1996) Apoptosis in procyclic Trypanosoma brucei in vitro. Cell Death Differ. 3, 77-82.

Wessels, D., Brincks, R., Kuhl, S., Stepanovic, V., Daniels, K.J., Weeks, G., Lim, C.J., Spiegelman, G., Fuller, D., Iranfar, N., Loomis, W.F., and Soll, D.R. (2004) RasC plays a role in transduction of temporal gradient information in the cyclic-AMP wave of Dictyostelium discoideum. Eukaryot. Cell. 3, 646-662.

Wiese, M. (1998) A mitogen-activated protein (MAP) kinase homoloque of Leishmania mexicana is essential for parasite survival in the infected host. EMBO J. 17, 2619-2628.

Wigler, M., Field, J., Powers, S., Broek, D., Toda, T., Cameron, S., Nikawa, J., Michaeli, T., Colicelli, J., and Ferguson, K. (1988) Studies of RAS function in the yeast Saccharomyces cerevisiae. Cold Spring Harb. Symp. Quant. Biol. 53, 649-655.

Wilkins, A., Khosla, M., Fraser, D.J., Spiegelman, G.B., Fisher, P.R., Weeks, G., and Insall, R.H. (2000) Dictyostelium RasD is required for normal phototaxis, but not differentiation. Genes Dev. 14, 1407-1413.

Yan, R., Small, S., Desplan, C., Dearolf, C.R., and Darnell, J.E. (1996) Identification of a Stat gene that functions in Drosophila development. Cell 84, 421-430.

Yarden, Y., and Ullrich, A. (1988) Molecular analysis of signal transduction by growth factors. Biochemistry 27 , 3113-3139.

Yoshida, N., Favoreto, S., Ferreira, A.T., and Mangue, P.M. (2000) Signal transduction induced in Trypanosoma cruzi metacyclic trypomastigotes during the invasion of mammalian cells. Braz. J. Med. Biol. Research. 33, 269-278.

Yoshida, M., Sendai, Y., Sakuragi, N., and Hotta, Y. (2000) Analysis of a mod B mutant in Dictyostelium discoideum using mRNA differential display. Plant Cell Physiol. 41, 239-243.

Zhang, Z., Smith, M.M., and Mymryk, J.S. (2001) Interaction of the e1a oncoprotein with yak1p, a novel regulator of yeast pseudohyphal differentiation, and related mammalian kinases. Mol. Biol. Cell. 12, 699710.

Zhou, Z., Gartner, A., Cade, R., Ammerer, G., and Errede B. (1993) Pheromone-induced signal transduction in Saccharomyces cerevisiae requires the sequential function of three protein kinases. Mol. Cell Biol. 13, 2069-2080. 


\section{Further Reading}

Caister Academic Press is a leading academic publisher of advanced texts in microbiology, molecular biology and medical research. Full details of all our publications at caister.com

- MALDI-TOF Mass Spectrometry in Microbiology Edited by: M Kostrzewa, S Schubert (2016) www.caister.com/malditof

- Aspergillus and Penicillium in the Post-genomic Era Edited by: RP Vries, IB Gelber, MR Andersen (2016) www.caister.com/aspergillus2

- The Bacteriocins: Current Knowledge and Future Prospects Edited by: RL Dorit, SM Roy, MA Riley (2016)

www.caister.com/bacteriocins

- Omics in Plant Disease Resistance Edited by: V Bhadauria (2016) www.caister.com/opd

- Acidophiles: Life in Extremely Acidic Environments Edited by: R Quatrini, DB Johnson (2016) www.caister.com/acidophiles

- Climate Change and Microbial Ecology: Current Research and Future Trend

Edited by: J Marxsen (2016)

www.caister.com/climate

- Biofilms in Bioremediation: Current Research and Emerging Technologies

Edited by: G Lear (2016)

www.caister.com/biorem

- Microalgae: Current Research and Applications Edited by: MN Tsaloglou (2016) www.caister.com/microalgae

- Gas Plasma Sterilization in Microbiology: Theory, Applications, Pitfalls and New Perspectives Edited by: H Shintani, A Sakudo (2016) www.caister.com/gasplasma

- Virus Evolution: Current Research and Future Directions Edited by: SC Weaver, M Denison, M Roossinck, et al. (2016) www.caister.com/virusevol

- Arboviruses: Molecular Biology, Evolution and Control Edited by: N Vasilakis, DJ Gubler (2016) www.caister.com/arbo

- Shigella: Molecular and Cellular Biology Edited by: WD Picking, WL Picking (2016) www.caister.com/shigella

-Aquatic Biofilms: Ecology, Water Quality and Wastewater Treatment

Edited by: AM Romaní, H Guasch, MD Balaguer (2016)

www.caister.com/aquaticbiofilms

- Alphaviruses: Current Biology

Edited by: S Mahalingam, L Herrero, B Herring (2016)

www.caister.com/alpha

- Thermophilic Microorganisms

Edited by: F Li (2015)

www.caister.com/thermophile
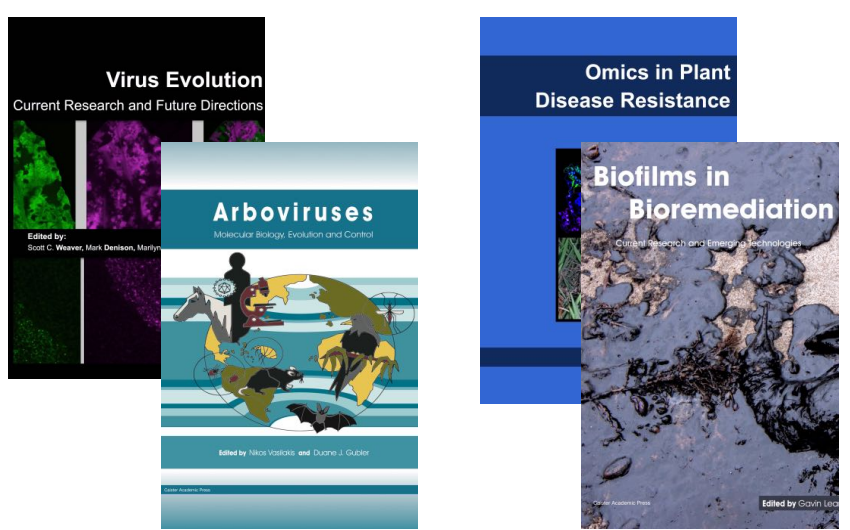
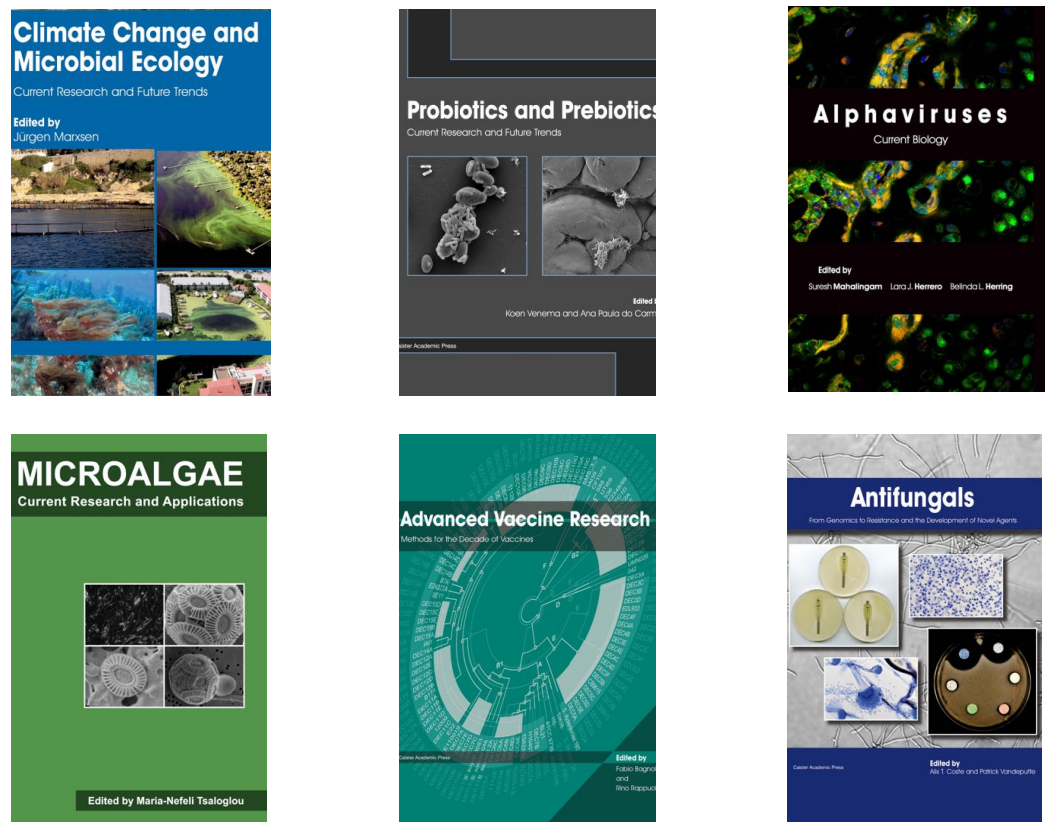

- Flow Cytometry in Microbiology: Technology and Applications Edited by: MG Wilkinson (2015) www.caister.com/flow

- Probiotics and Prebiotics: Current Research and Future Trends Edited by: K Venema, AP Carmo (2015) www.caister.com/probiotics

- Epigenetics: Current Research and Emerging Trends Edited by: BP Chadwick (2015) www.caister.com/epigenetics2015

- Corynebacterium glutamicum: From Systems Biology to Biotechnological Applications

Edited by: A Burkovski (2015)

www.caister.com/cory2

- Advanced Vaccine Research Methods for the Decade of Vaccines

Edited by: F Bagnoli, R Rappuoli (2015)

www.caister.com/vaccines

- Antifungals: From Genomics to Resistance and the Development of Novel Agents

Edited by: AT Coste, P Vandeputte (2015)

www.caister.com/antifungals

- Bacteria-Plant Interactions: Advanced Research and Future Trends Edited by: J Murillo, BA Vinatzer, RW Jackson, et al. (2015) www.caister.com/bacteria-plant

\section{- Aeromonas}

Edited by: J Graf (2015)

www.caister.com/aeromonas

- Antibiotics: Current Innovations and Future Trends

Edited by: S Sánchez, AL Demain (2015)

www.caister.com/antibiotics

- Leishmania: Current Biology and Contro Edited by: S Adak, R Datta (2015) www.caister.com/leish2

- Acanthamoeba: Biology and Pathogenesis (2nd edition) Author: NA Khan (2015)

www.caister.com/acanthamoeba2

- Microarrays: Current Technology, Innovations and Applications Edited by: Z He (2014)

www.caister.com/microarrays2

- Metagenomics of the Microbial Nitrogen Cycle: Theory, Methods and Applications

Edited by: D Marco (2014)

www.caister.com/n2 